\title{
Polska tolerancja czy początki oświecenia? Jonasz Szlichtyng (1592-1661) jako teolog „drugiej reformacji”
}

\section{Pamięci Ludwika Chmaja}

Jan Amos Komeński, pastor gminy w Lesznie i superintendent Jednoty Braci Czeskich, pisał po rozpoczęciu najazdu szwedzkiego w roku 1655: „Sytuacja zarówno wewnątrz kraju, jak i na zewnątrz była tak zła, iż gorszą trudno już sobie wyobrazić. Na zewnątrz barbarzyńscy wrogowie czyhali na dobra i życie; wewnątrz kłamliwi przyjaciele zagrażający wolności zarówno religijnej jak i politycznej. Sprawy doszły do tego, że Polska [...] mogła być uważana raczej za trupa Rzeczypospolitej”1.

1 Artykuł był przygotowywany w latach 2010-2012 dzięki wsparciu MNiSzW oraz Fundacji na rzecz Nauki Polskiej. Fragmenty rozważań zostały przedstawione na zebraniu Zakładu Historii Nowożytnej Instytutu Historycznego UW (7 XII 2011) oraz na konferencji Polski Barok, Europejskie Konteksty (Instytut Badań Interdyscyplinarnych „Artes Liberales” UW, 27 VI 2011), a także opublikowane w artykule: Jonasz Szlichtyng (1592-1661) - the Forgotten Arian Theologian of the 17th Century?, w: Polish Baroque, European Contexts, ed. P. Salwa, Instytut Badań Interdyscyplinarnych „Artes Liberales”, Warsaw 2012, s. 163-182. Autor pragnie podziękować uczestnikom za dyskusję oraz prof. Urszuli Augustyniak za szereg inspirujących i krytycznych uwag.

Panegyricus Carolo Gustavo, magno Suecorum Vandalorumq[ue] Regi, incruento Sarmatiae Victori et quaqua uenit liberatori pio, felici, Augusto, [b.m. i druk.], 1655; edycja: Johannis Amos Comenii opera omnia, Academia, Praha 1974, t. 13, s. 67-94, tu: s. 73 („Res hic tam male steterant, ut pejus non possent, foris domique. Foris erant barbari hostes bonis et vitae: domi simulati amici libertatibus inhiantes religiosis et politicis"). Polskie tłumaczenie: Panegiryk Karolowi Gustawowi bezkrwawemu zwycięzcy Sarmacji, 
To jednak nie potop szwedzki skłonił go do sformułowania takiej oceny. Wręcz przeciwnie, zdaniem czeskiego teologa władca Szwecji, Karol X Gustaw, był jedynym ratunkiem dla Polski. Komeński nie tylko chwalił cnoty króla, lecz także napominał go, aby podążał za dobrymi radami oraz unikał pochlebców i „makiawelistów”. Przede wszystkim powinien jednak zadbać o polską wolność, ponieważ „wolnym nie będzie mógł rozkazywać inaczej, jak tylko w sposób godny ludzi wolnych”.

Panegiryk Komeńskiego ukazał się jako anonimowe, łacińskie pismo ulotne. Natychmiast wzbudziło ono ogromne zainteresowanie opinii publicznej i zostało przedrukowane we Wrocławiu, Norymberdze, Frankfurcie, Londynie oraz Paryżu ${ }^{2}$. Jednak oddzielenie patriotyzmu od lojalności wobec władcy sprawiło, że duchowny został posądzony o zdradę ${ }^{3}$. Odium zdrady rozciągnięto na szersze kręgi protestantów, a następnie zrzucono na arian, którzy bardzo długo korzystali z ochrony Karola Gustawa. Pisma Komeńskiego i ich recepcja wyznaczają linię demarkacyjną między długim trwaniem tradycji tolerancyjnego wieku XVI a nietolerancją XVII stulecia. Pochwała wolności stała się podstawą do oskarżeń o zdradę.

w: Filozofia i myśl spoteczna XVII wieku, oprac. Z. Ogonowski, t. 1, PWN, Warszawa 1979, s. 280-298.

2 Johannis Amos Comenii opera omnia, s. 84. Na temat panegiryku por. V. Urbánek, J. A. Comenius' Anti-Machiavellianism, „Acta Comeniana”, 1995, 11, s. 61-70; J. Beer, Advice to princes in the work of J. A. Comenius and Erasmus of Rotterdam, w: Comenius und der Weltfriede, hrsg. von W. Korthaase, S. Hauff, A. Fritsch, Deutsche Comenius-Gesellschaft, Berlin 2005, s. 108-117; J.-C. Margolin, Érasme et Coménius, w: Jan Amos Coménius (1592-1670). Aspects culturels, philosophiques, pédagogiques et didactiques de son auvre, ed. J. A. Caravolas, G. Bibeau, Université de Montréal, Montreal 1996, s. 149-179; J. Dworzaczkowa, „Panegyricus Carolo Gustavo” i jego tto polityczne, OiRwP, 1982, 27, s. 93-105 [przedr. w: Ead., Reformacja i kontrreformacja $w$ Wielkopolsce, Wydawnictwo Poznańskie, Poznań 1995, s. 311-328]; H.-J. Müller, The dimensions of religious toleration in the eirenicism of Jan Amos Comenius (1642-1645), „Acta Comeniana”, 2003, 17, s. 99-116; D. Rott, Polityka a literatura. „Panegyricus Carolo Gustavo" Jana Amosa Komeńskiego wobec kultury sarmackiej, w: Sarmackie teatrum, red. R. Ocieczek, t. 1, Wydawnictwo UŚ, Katowice 2001, s. 72-89.

3 Por. negatywne oceny publicystyki historycznej: J. Giertych, U źródet katastrofy dziejowej Polski: Jan Amos Komensky, [b. wyd.], London 1964; M. Mścisz, Amos Komensky w walce z państwem polskim, „Kurier Literacko-Naukowy” (3 II 1935), s. 6-8. Bardziej wyważone oceny w: A. Danysz, Jan Amos Komeński: przyczynki do jego dziatalności w Polsce, „Roczniki Towarzystwa Przyjaciół Nauk Poznańskiego”, 1899, 25, s. 109-202 (zwłaszcza s. 125-126); hasło „Komeński”, w: PSB, t. 13, s. 385-389. 
Wizję chwalącą wolność wyznaniową XVI w., ganiącą nietolerancję XVII stulecia i gloryfikującą tolerancję XVIII w. stworzyli już luminarze oświecenia, a wśród setek późniejszych autorów i popularyzatorów należy wskazać: Stanisława Kota, Marka Wajsbluma, Ludwika Chmaja, Janusza Tazbira czy Zbigniewa Ogonowskiego. Ostatnio potwierdził ją także Wojciech Kriegseisen, twierdząc, iż „o ile Rzeczpospolitą początków XVII w. zaliczano jeszcze do najbardziej tolerancyjnych państw Europy, o tyle $\mathrm{w}$ drugiej połowie tego stulecia straciła tę pozycję. To zapewne wtedy narodził się syndrom 'Polak = katolik', który skutkował wykluczeniem innowierców ze wspólnoty obywateli Rzeczypospolitej”“4

W tej tradycyjnej wizji stosunek do braci polskich odgrywa szczególną rolę. Zamknięcie zboru, drukarni i szkoły w Rakowie (1638), spalenie ich wyznania wiary (1647) oraz nakazy konwersji lub opuszczenia Rzeczypospolitej (1658) stanowią oznaki końca epoki szerokiej tolerancji ${ }^{5}$. Stosunek do arian jest więc kwestią relacji między dominującą ortodoksją (protestancką lub katolicka) a ograniczaną i wykluczaną heterodoksją. W tradycyjnych ujęciach dominowały interpretacje apologetyczne lub oskarżycielskie, korzystające obficie $\mathrm{z}$ argumentów formułowanych w publicystycznych starciach w XVII w. W ich świetle walka o prawa heterodoksji była - w oczach apologetów - zmaganiem o tolerancję i poszanowanie praw ${ }^{6} . Z$ kolei dla oskarżycieli zwolennicy heterodoksji byli zdrajcami pozbawionymi patriotyzmu ${ }^{7}$, którzy burzyli porządek

4 W. Kriegseisen, Stosunki wyznaniowe w relacjach państwo-kościót między reformacja a oświeceniem (Rzesza Niemiecka, Niderlandy Pótnocne, Rzeczpospolita polsko-litewska), Wydawnictwo Naukowe Semper, Warszawa 2010, s. 668. Por. obszerne omówienie książki w recenzji G. Wąs (OiRwP, 2011, 45, s. 379-404).

5 W. Kriegseisen, Stosunki wyznaniowe, s. 618-660; Id., Ewangelicy polscy i litewscy w epoce saskiej (1696-1763), Wydawnictwo Naukowe Semper, Warszawa 1996, s. 19-49. Por. M. Wajsblum, Ex regestro arianismi. Szkice z dziejów upadku protestantyzmu $w$ Matopolsce, RwP, 1935-1936, 7/8, s. 245-308.

6 Por. J. J. Kolarzowski, Idea praw jednostki w pismach braci polskich. U narodzin nowożytnej koncepcji praw cztowieka, Wydawnictwa UW, Warszawa 2009, s. 141, 146-147, 211 (bracia polscy „to grupa heroiczna, moralna, w większości patriotyczna i działająca zgodnie z regułami szeroko pojętego racjonalizmu”).

7 Por. J. Dzięgielewski, Stosunek arian do państwa polskiego, mps BUW (sygn. 507148), s. 8 (arianie „pozostali kosmopolitami starającymi się osłabić patriotyzm współwyznawców”), 22 („działalność elity zborowej zmierzała bądź do osłabienia Rzeczypospolitej i jej zneutralizowania, bądź do związania z europejskim obozem protestanckim”), 17 („stosunek arian do państwa polskiego zawsze był nieprzychylny”). Artykuł, odrzucony w 1981 r. przez redakcję OiRwP, został przedrukowany w: Id., O ustroju, decydentach 
społeczny i religijny ${ }^{8}$. Zarówno obrońcy, jak i oskarżyciele łamali przy tym zasady hermeneutyki, wyrywając cytaty z kontekstu i rozbijając ciągi argumentacyjne; tracili tym samym z oczu teologiczny - i polemiczny - kontekst wielu wypowiedzi. Chcąc nadać sens i znaczenie interpretowanym treściom, odnosili je do współczesnych wartości'.

Temu ujęciu należy przeciwstawić inne spojrzenie, które abstrahuje od wartości i odrzuca prezentyzm apologii i oskarżeń. Uwzględnienie kontekstu formułowanych sądów zmusza do przedstawienia wypowiedzi na szerszym tle teologicznym oraz intelektualnym. Teologiczne debaty zasługują na uważne odczytanie nie tylko jako dzieje abstrakcyjnych doktryn, lecz również jako fragment historii myśli, odnoszący się do ówczesnego świata wartości i jego bardzo bogatej historii sporów.

Poniżej owe abstrakcyjne tezy poparto analizą poglądów Jonasza Szlichtynga, głównego teologa i przywódcy braci polskich w epoce prześladowań i wygnania. W analizie wykorzystano przede wszystkim utwory polemiczne Szlichtynga, które ukazały się za jego życia, abstrahując zaś od pism stricte egzegetycznych, wydanych post mortem w edycji Bibliotheca Fratrum Polonorum $^{10}$. Kolejno omówiono biografię i publikacje teologa,

i dysydentach. Studia i szkice z dziejów Pierwszej Rzeczypospolitej, Wydawnictwo i Poligrafia Kurii Prowincjalnej Zakonu Pijarów, Kraków 2011, s. 175-187. Tezy publikacji są nadal podtrzymywane przez autora oraz przywoływane w najnowszych opracowaniach. Por. Id., Od staropolskiego „mitośnika ojczyzny”, do „sarmackiego patrioty”, w: Patriotyzm Polaków. Studia z historii idei, wyd. J. Kloczkowski, Ośrodek Myśli Politycznej, Kraków 2007, s. 21-31 (zwłaszcza s. 27, przyp. 14); J. Choińska-Mika, Między spoteczeństwem szlacheckim a wtadza. Problemy komunikacji: spoteczności lokalne - wtadza w epoce Jana Kazimierza, Neriton, Warszawa 2002, s. 194. Por. krytykę artykułu Dzięgielewskiego oraz całej wizji w: J. Tazbir, Przyczyny banicji arian z Polski, „Przegląd Humanistyczny”, 1999, 2/3, s. 13-24. Skrócona wersja artykułu Tazbira, bez krytycznych uwag, w: Id., Ursachen der Verbannung der Sozinianer aus Polen, w: Faustus Socinus and his heritage, ed. L. Szczucki, PAU, Kraków 2005, s. 229-242.

8 Zarzuty powtórzył ostatnio bezkrytycznie J. Żukowski, Kije strugane, czyli ikonoklazm braci polskich, „Quarta”, 2011, 20, s. 27-44. Artykuł jest chybioną polemiką z tezami zawartymi w starszych publikacjach, m.in. S. Michalskiego, poświęconych zagadnieniu obrazoburstwa. Por. rzeczowy obraz propagandy antyariańskiej i replik braci polskich w: S. Radoń, $Z$ dziejów polemiki antyariańskiej $w$ Polsce XVI-XVII wieku, Universitas, Kraków 1993, s. 17-22.

9 Obszerniej na ten temat piszę w recenzji z pracy J. J. Kolarzowskiego (OiRwP, 2012, 20, s. 261-272).

10 Wbrew opinii Z. Ogonowskiego, który uważa, że „spuścizna pisarska [Szlichtynga] objęta została niemal w całości [...] w osobnym woluminie Bibliotheca Fratrum Polonorum. 
a następnie jego poglądy teologiczne, koncentrując się na trynitologii, chrystologii i soteriologii oraz stosunku do władzy kościelnej i świeckiej. Postąpiono tak nie tylko po to, aby ukazać tło wydarzeń historycznych, lecz przede wszystkim, aby - traktując historię teologii jako fragment dziejów myśli - udowodnić, że polemiczny kontekst, w którym formułowano określone sądy, był istotny dla treści formułowanego przekazu. Główna teza poniższych rozważań głosi, że Szlichtyng jako teolog ariański podją próbę zbliżenia braci polskich do wyznania reformowanego. Na tę próbę Kościół katolicki (a zapewne także kościoły protestanckie), wykorzystując państwowe instytucje, odpowiedział spaleniem jego Konfesji w Warszawie w 1647 r. i wygnaniem arian w 1658 r. Bracia polscy dołączyli wówczas do grupy exules, europejskich migrantów i wygnańców religijnych, do których należeli bracia czescy (wygnani z monarchii Habsburgów w 1548 i 1627 r.), hugenoci (1685) czy wcześniej angielscy protestanci (1553-1558), a także liczni duchowni pojedynczych gmin zmuszani do porzucania ojczyzny wraz ze zmianą konfesji władcy ${ }^{11}$.

Człowiek i dzieło

Biografia Jonasza Szlichtynga jest dobrze znana w ogólnych zarysach ${ }^{12}$. Teolog urodził się najprawdopodobniej 1592 r. w Sączkowie koło Śmigla w rodzinie niemieckiej szlachty. Był synem Wolfganga Schlichtynga (zm.

Obejmuje ona przede wszystkim pisma egzegetyczne" (Myśl ariańska w Polsce XVII wieku. Antologia tekstów, oprac. Z. Ogonowski, PWN, Warszawa 1991, s. 567). Por. zupełnie błędny pogląd, iż „pisma Przypkowskiego i Szlichtinga, mające przede wszystkim przeciwdziałać szerzeniu się wśród braci radykalnych poglądów J. L. Wolzogena, J. Stegmana (młodszego) i D. Zwickera, pozostawały w rękopisach, cenzorzy ze zborowego kierownictwa nie dopuścili ich nawet do druku”, w: J. Dzięgielewski, Stosunek arian, s. 9. Wykaz prac Szlichtynga podaje bibliografia Estreichera, a także: Nowy Korbut, oprac. R. Pollak, IBL PAN, Warszawa 1965, t. 3, s. 314-315. Najnowsze opracowanie: Bibliographia Sociniana. A bibliographical reference tool for the study of Dutch socinianism and antitrinitarism, ed. P. Knijff, S. J. Visser, Uitgeverij Verloren, Amsterdam 2004, nr 2001-2003, 2010, 2023-2026, 2030, 2094-2114, 4123, 6083, 6399, 6551.

11 Por. J. Tazbir, Przyczyny banicji, s. 21-22.

12 Zwięzłe przedstawienie biografii: W. Dworzaczek, Schlichtyngowie w Polsce, Gebethner i Wolff, Warszawa 1938, s. 26-40; szkic biograficzny S. Lubienieckiego: Exemplum Epistolae Stanislai Lubieniecii de Lubienietz, jako wstęp do: Bibliotheca Fratrum Polonorum, t. 3, cz. 1, Irenopoli 1656 [właśc. Amsterdam 1668] (strony nienumerowane); Z. Śniechowska, Jonasz Schlichting z Bukowa, Kraków 1936 (praca powstała na seminarium S. Kota; rkps w Archiwum UJ, sygn. WF II 505); M. Ptaszyński, Szlichtyng Jonasz, w: PSB, t. 48, cz. 3 (z. 198), s. 398-403; Id., Jonasz Szlichtyng (1592-1661), s. 164-171. 
1608 lub 1612) i Barbary z Arciszewskich. Po odebraniu starannej edukacji działał w latach 1620-1638 jako polemista, a także pastor i wykładowca w Rakowie, gdzie blisko współpracował z Janem Krellem (Crelliusem, zm. 4 VII 1633). Po zamknięciu Rakowa wyrokiem sejmu w 1638 r. Szlichtyng przeniósł się wraz z częścią gminy do Lusławic. Wówczas, w 1639 r., synod zlecił mu sporządzenie wyznania wiary, które ukazało się drukiem w roku $1642^{13}$. Jego publikacja zbiegła się w czasie z rozpoczęciem przygotowań do Colloquium Charitativum, które ostatecznie zebrało się w Toruniu w 1645 r. Szlichtyng przybył tam wraz z delegacją braci polskich, lecz nie został dopuszczony do rozmów ${ }^{14}$. Podczas sejmu, który zebrał się w Warszawie 9 maja 1647 r., odbył się sąd sumaryczny nad Confessio fidei. Szlichtyng został oskarżony o zbrodnię obrazy boskiego majestatu i Rzeczypospolitej („,crimen laesae Divinae Maiestatis et Reipublicae”) ${ }^{15}$. Dnia 11 maja 1647 r. nakazano publiczne spalenie w Warszawie egzemplarza wyznania oraz zakazano rozpowszechniania i posiadania książki. Szlichtyng został skazany na karę śmierci, infamię oraz konfiskatę majątku. Po wyroku teolog często zmieniał miejsca pobytu. W czasie potopu przybył do Krakowa, gdzie podjął także ponownie aktywność pisarską, którą przerwała dopiero śmierć w $1661 \mathrm{r}$.

Jego pisma polemiczne i egzegetyczne można podzielić chronologicznie na trzy grupy: wczesne polemiki, które ukazywały się w latach 1625-1637; przygotowanie i druk wyznania wiary (1639-1642); utwory publikowane po 1643 r., czyli późne polemiki (w większości niewydane), pisma apologetyczne oraz katechetyczne.

W pierwszym okresie (1625-1637) Szlichtyng polemizował z reformowanym duchownym Danielem Clementinusem (zm. 1644) ${ }^{16}$

13 S. Szczotka, Synody Arian, RwP, 1936, 7-8, s. 81; [J. Schlichting], Confessio fidei Christianae edita nomine Ecclesiarum Polonicarum quae unum Deum et Filium eius unigenitum Jesum Christum cum Spiritu Sancto profitentur, [b. druk.], [Lusławice?] 1642; informacje bibliograficzne por. przyp. 10.

14 Por. H.-J. Müller, Irenik als Kommunikationsreform. Das Colloquium Charitativum von Thorn 1645, Vandenhoeck \& Ruprecht, Göttingen 2004, s. 233-235, 419-421.

15 Przedrukowany w: L. Chmaj, Samuel Przypkowski, PAU, Kraków 1927, s. $45-46$ oraz w: W. Dworzaczek, Schlichtyngowie, s. 31, przyp. 1. Parafraza wyroku i opis procesu także w dziele Szlichtynga: Confessionis Christianae ad rogum damnatae \& combustae manium a Rev. D. Nicolao Cichovio lacessitorum sui vindices, [b. druk., b.m.], 1652, s. 15-18.

16 Por. informacje biograficzne w: S. Szczotka, Clementinus Daniel, w: PSB, t. 4, s. 90-91; A. Węgierski, Libri quattuor Slavoniae reformatae, ed. J. Tazbir, PWN, Varsoviae 1973, s. 115. 
i luteraninem Balthasarem Meisnerem (1587-1626) ${ }^{17}$. Druk Daniela Clementinusa, który wywołał reakcję Szlichtynga i skłonił go do sięgnięcia po pióro, ukazał się w Krakowie w 1623 r. i nosił prowokujący tytuł $A n$ tilogiae et absurda to jest sprzeciwieństwa i niestuszności wyptywające z opiniej Socinitów ponurzonych. Kalwiński minister atakował antytrynitarzy już od 1618 r., ścierając się z Hieronimem Moskorzowskim, Szymonem Pistoriusem oraz występując w 1624 r. na pogrzebie Jana Glińskiego ${ }^{18}$. Publikacja Clementinusa nie wynikała jedynie z jego żywego temperamentu, lecz była świadomą i przemyślaną decyzją małopolskiej Jednoty Reformowanej, która na konwokacji i synodach w Górach w 1623, 1624 i 1626 r. zdecydowała o rewizji i druku dzieła oraz jego kontynuacji ${ }^{19}$. W 1630 r. Clementinus wydał kolejny traktat, polemizując już wprost ze Szlichtyngiem: Antapologia, to iest Odpowiedż X. Daniela Clemenitnusa, na Odpowiedź p. Jonasza Szlichtinka.

Swoje obszerne repliki Szlichtyng spisał w języku polskim i wydał w latach 1625 („odpowiedź”) i 1631 (jako „odpowiedź na odpowiedź na odpowiedź”), dedykując je protektorowi ewangelików reformowanych oraz braci czeskich, Rafałowi Leszczyńskiemu ${ }^{20}$. Odpowiedź opatrzył także posłowiem adresowanym do „Panów Ewangelików”, których nakłaniał do nieufności w stosunku do pastorów, zwłaszcza tych, „którzy nauczycielami będąc, nie radzi by się stali uczniami”"21. Żeby swą pracę uczynić jeszcze bardziej przystępną, Szlichtyng przełożył na polski również cytaty przytaczane przez adwersarza po łacinie ${ }^{22}$.

Trzy części repliki odpowiadały strukturze Antilogii Clementinusa i były to: oczyszczenie z zarzutów (s. 1-77), obrona wyznania braci

17 W. Sparn, Meisner, Balthasar, w: Biographisch-Bibliographisches Kirchenlexikon, t. 5, Traugott Bautz, Herzberg 1993, szp. 1172-1174.

18 M. Pawelec, Barttomiej Bythner starszy (ok. 1559-1629), Wydawnictwo Naukowe Semper, Warszawa 2008, s. 87, 89-90.

19 Akta Synodów Różnowierczych w Polsce, wyd. M. Sipayłło, BUW, Warszawa 1983, t. 3, s. 443, 461, 489. Por. M. Pawelec, op. cit., s. 89; S. Radoń, op. cit., s. 23-24.

20 Odpowiedź na script X. Daniela Clementinusa, Nazwany; Antilogiae et absurda, to jest, Sprzeciwienstwa, y niestuszności wyptywające z opiniy Socinitów Ponurzonych uczyniona przez Jonasza Szlichtinga z Bukowca, druk. S. Sternacki, Raków 1625; Na Antapologia ks. Daniela Clementiusa o potwarzach odpowiedź, druk. S. Sternacki, Raków 1631, s. 4-16. 21 Odpowied'́, s. 245-246.

22 Ibidem, k. xx2v (,iż się niemało tu y owdzie łaciny mieszało, żeby cię to, ieśli po łacinie nieumiesz, od czytania nie odrażało, podiąłem się ieszcze tey prace, żem na końcu książki, co potrzebnieysze mowy łacińskie na polskie przełożył”). 
polskich (127-146) oraz wykazanie różnic dzielących ich od zboru większego (147-232). W pierwszej części arianin rozprawił się z tradycyjnymi argumentami wysuwanymi przeciw zborowi mniejszemu. Ich katalog pozostawał niezmienny od kilkudziesięciu lat: braciom polskim zarzucano negację boskości Chrystusa oraz znaczenia jego ofiary, odrzucanie Ducha Świętego, podważanie koncepcji grzechu pierworodnego i predestynacji oraz skłonność do judaizmu. Szlichtyng odpierał także zarzuty dotyczące sposobu prowadzenia się ministrów ariańskich, którym od kilkunastu lat wytykano, że nie zawsze żyją w zgodzie z głoszonymi ideałami ubóstwa ${ }^{23}$. Bronił również mieszkańców Rakowa, gdzie podobno okradziono szlachcica, Krzysztofa Cikowskiego ${ }^{24}$, zarazem ostro sprzeciwiał się stylowi polemiki Clementinusa, nieszczędzącego socynianom epitetów, wśród których „nurkowie”, „komornicy wodni” czy „mędrkowie” należały do bardziej oględnych ${ }^{25}$.

W drugim dziele polemizującym z Clementinusem Szlichtyng słusznie zauważył, że Antapologia nie była samodzielnym tworem reformowanego teologa ${ }^{26}$. Mimo iż - jak pisze - „kto był tym Patronem, zgadnąć nam nie trudno", Szlichtyng nie podał nigdy jego nazwiska. Dziś wiadomo, że współautorami byli najprawdopodobniej Bartłomiej Bythner (zm. 1629) oraz Tomasz Węgierski ${ }^{27}$. W drugiej replice Szlichtyng zauważył, że wiele argumentów reformowany teolog czerpał z traktatów luteranina, Balthasara Meisnera ${ }^{28}$, co skomentował słowami: „Aleć i Meisnerus będzie

23 Odpowiedź, s. 24 („Pieszczonych Ministrów z łaski Bożey nie mamy, i którzy by się za Plebaniami bogatszemi na Synodach uganiali, ale takie, którzy za Synodowym postanowieniem, na wszelkie miejsce prowadzić się gotowi, i tam chwale Bożey służyć, i dla tego się w żadne domy, i wczasiki nie fundują. Żadnego też tak dostatniego nie wiem (choć się ich wiele zacnymi Szlachcicami porodziło), któryby miał co nad przystojne obeście swoje i domu swego, i owszem naydą się tacy, którzy majętności i dostatki swoje, chwale Bożej służąc potracili”), 28; Na Antapologia [...] odpowiedź, s. 177-179.

24 Na Antapologia [...] odpowiedź, s. 329.

25 Odpowiedź, s. 92-95. Por. S. Radoń, op. cit., s. 91-118.

26 Na Antapologia [...] odpowiedź, s. 1 („Widziano to bez pochyby jako źle X. Celm. stanąt, i dlatego mu Patrona przydano, który imię jego na się wziąwszy, usiłuje podeprzeć causy jego. Co dla tego przypominam, żeby nas za takie prostaki nie miano, jakobyśmy się w tym nie postrzegali. Widzimy to barzo dobrze").

27 M. Pawelec, op. cit., s. 113-114.

28 Na Antapologia [...] odpowiedź, s. 290, 292. 
miał da P. Bóg swoją odpowiedź" ${ }^{29}$. Wówczas też rozpoczął zapewne pracę nad nową dysputacją ${ }^{30}$.

Szlichtyng zdawał sobie sprawę, że Meisner należał do najwybitniejszych teologów luterańskiej ortodoksji: już w 1613 r., mając niespełna 26 lat, otrzymał katedrę teologii na uniwersytecie w Wittenberdze i był jednym z głównych adwersarzy w sporze o stosunek teologii i filozofii, wywołanym przez Daniela Hoffmanna, profesora z Helmsted ${ }^{31}$. Zabrał także głos w sporze o krypsis i kenosis, wywołanym przez profesorów z Tybingi i Gießen, najważniejszym i najdonioślejszym sporze ortodoksji luterańskiej pierwszej połowy XVII w. ${ }^{32}$ Polemikę zdołał Szlichtyng ukończyć w 1635 r., nie wiedząc, że Meisner od 9 lat nie żył3 ${ }^{33}$. W następnych latach wydał obszerniejsze wersje swej debaty z wittenberskim profesorem, rozszerzając ją o kolejne zagadnienia ${ }^{34}$. Pierwszy tom Szlichtyng dedykował swemu, należącemu do Jednoty Braci Czeskich, kuzynowi Janowi Jerzemu Szlichtyngowi, drugi - wydany w 1636 r. - Adamowi i Andrzejowi Gosławskim, prominentnym postaciom społeczności

\section{Ibidem, s. 16.}

30 Za taką wczesną datacją przemawia wzmianka o panowaniu Zygmunta III Wazy w: Ionae Schlichtingii a Bukowiec De ss. Trinitate, de moralibus N.\&V. Testamenti praeceptis, itemque de Sacris, Evcharistiae, \& Baptismi ritibus. Adversus Balthasarem Meisnerum, Sacrae Theol. Doctorem, et in Acad. Vittebergensi, Professorem Publicum, druk. S. Starnacki/J. Lange, b.m. [Raków] 1637, s. 277-278. Por. S. Radoń, op. cit., s. 23-24; A. Kawecka-Gryczowa, Ariańskie oficyny wydawnicze Rodeckiego i Starnackiego, Ossolineum, Wrocław 1974, s. 65-66.

31 Por. M. Friedrich, Die Grenzen der Vernunft. Theologie, Philosophie und Konflikte am Beispiel des Helsmstedter Hoffmannstreits und seiner Wirkungen auf das Luthertum um 1600, Vandenhoeck \& Ruprecht, Göttingen 2004, s. 210-211, 301-303, 365-368. 32 Por. U. Wiedenroth, Krypsis und Kenosis. Studien zu Thema und Genese der Tübinger Christologie im 17. Jahrhundert, Mohr Siebeck, Tübingen 2011, s. 358-362, 411-415, 437-449.

33 Por. Quaestio Num ad regnum Dei possidendum necesse sit in nullo peccato Evangelicae doctrinae adverso manere? contra Balthasarem Meisnerum, Typis Pauli Sternacii, [Raków] 1635, k. 6v. Por. błędna uwaga K. Estreichera, że Meisner zmarł „w ciągu druku odpowiedzi Schlichtynga” (Id., Bibliografia polska, PAU, Kraków 1930, cz. 3, t. 27, s. 213. Dostępne w internecie: http://www.estreicher.uj.edu.pl/).

34 Por. Questiones dua: vna Num in evangelicorum religione dogmata habeantur, quae vix ullo modo permittant, ut qui eam amplectatur, nullo in peccato perseveret? Altera Num in eadem religione quaedam concedantur Christi legibus inconcessa? contra Balthasarem Meisnerum S. Theologiae Doctorem et in Academia Witenbergensi Profess. publicum a Jona Schlichtingio a Bukowiec disputatae, Typis Pauli Sternacii, Raków 1636. 
ariańskiej ${ }^{35}$. W 1637 r. Szlichtyng opublikował trzecią i ostatnią polemikę z Meisnerem, poprzedzoną przedmową adresowaną do duchownych i uczonych wszystkich kościołów chrześcijańskich w Europie ${ }^{36}$.

Punktem wyjścia dla rozważań w pierwszym utworze skierowanym przeciw Meisnerowi, stanowiącym też apologię Fausta Socyna, było pytanie, czy do zbawienia („ad regnum Dei possidendum”) niezbędne było pozostanie bez grzechu i świątobliwe życie („vitae sanctitas”) ${ }^{37}$. Szlichtyng bronił tezy, iż grzeszenie nie oznacza ipso facto przynależności do grona potępionych ${ }^{38}$. Problem ten dotykał najistotniejszych elementów myśli protestanckiej: koncepcji usprawiedliwienia przez wiarę oraz predestynacji, a także znaczenia ofiary Chrystusa oraz dobrych uczynków. Wszystkie te zagadnienia Szlichtyng poruszył rok później, przedrukowując duże fragmenty Quaestio oraz dodając obszerny ustęp na temat stosunku do zwierzchności świeckiej, wojny oraz heretyków (Quaestiones duae). Ostatnia polemika (De ss. Trinitate) była obroną stanowiska Socyna w sprawie Boga i Trójcy świętej (s. 63-386), osoby Chrystusa (s. 386-603), Ducha Świętego (s. 603-669), wypełniania nakazów Prawa i stosunku do Starego Testamentu (s. 669-700), eucharystii (s. 700-830) oraz chrztu (s. 830-945). W ogromnym, tysiącstronicowym opus Szlichtyng przytaczał, wyjaśniał i komentował obszerne fragmenty z pism Socyna ${ }^{39}$ i z dzieła Meisnera $^{40}$, w którym luterański teolog atakował socynianów.

Dobór adwersarzy w pierwszym okresie nie był przypadkowy: byli to młodzi teologowie ortodoksji protestanckiej, wspinający się szybko po szczeblach kariery i atakujący z gorliwością arywistów inne konfesje. Podejmując te dysputy, Szlichtyng wyznaczał miejsce zboru mniejszego wśród kościołów protestanckich w Rzeczypospolitej. Po ich opublikowaniu poświęcił się pracom nad wyznaniem wiary (w latach 1639-1642), co

35 Por. A. Kossowski, Gostawski Adam, w: PSB, t. 8, s. 354-355.

36 Por. De ss. Trinitate.

37 Quaestio, k. 6v-7r.

38 Quaestio, k. 7v.

39 Przede wszystkim atakowane przez Meisnera traktaty Socyna: Quod regni Poloniae, \& magni ducatus Lithuaniae homines, vulgo Evangelici dicti, qui solidae pietatis sint studiosi, omnino deberent se illorum coetui adjungere, qui in iisdem locis faslo atque immerito Arriani et Ebonitae vocantur, w: Bibliotheca Fratrum Polonorum, t. 1, cap. 3, s. 696-707; De baptismo aquae. An homini Christiano aquae baptismo carere liceat, w: ibidem, s. 709-738.

40 B. Meisner, Brevis consideratio theologiae Photinianae, Excudebant Haeredes Johannis Richteri, impensis Caspari Heiden, Wittenberg 1619. 
zamknęło ten okres budowania świadomości wyznaniowej - zarówno samego Szlichtynga, jak i zboru mniejszego. W tym okresie (1637-1643) arianin wstrzymał się z publikowaniem dzieł polemicznych. Dopiero po ukazaniu się konfesji Szlichtyng sięgnął po pióro polemisty, dyskutując z Hugonem Grotiusem, Georgiem Vechnerem oraz z jezuitą Mikołajem Cichowskim. Nie zdecydował się natomiast na opublikowanie drugiej, obszerniejszej polemiki z Grotiusem oraz z Janem Amosem Komeńskim ${ }^{41}$. Podobnie prywatny charakter zachowała jego wymiana opinii z Johannem Ludwigiem von Wolzogenem. W okresie tym Szlichtyng bronił wyznania wiary i pracował nad rewizją Katechizmu Rakowskiego.

Pierwszą polemikę z traktatem Hugona Grotiusa Szlichtyng opublikował w roku 1643, ukrywając się pod pseudonimem Simplicius ${ }^{42}$. Jak przypuszczał Chmaj, Szlichtyng wydał dzieło „z polecenia swoich współwyznawców", a nie zdecydował się drukować pod własnym nazwiskiem, „by ukryć źródło pochodzenia książki”ł3. Ireniczny klimat poprzedzający Colloquium Charitativum w Rzeczypospolitej, skłaniający do podjęcia rozmów między podzielonymi wyznaniami, nie sprzyjał sporom religijnym. Zarazem należy pamiętać, że stosunek socynianów do Grotiusa był niezwykle złożony. Bliski współpracownik Johana van Oldenbarnevelta otwarcie wspierał piórem remonstrantów, z którymi socynianie utrzymywali bliskie relacje, jednak po ich porażce został uwięziony i musiał emigrować do katolickiej Francji. Następnie nie tylko dedykował Ludwikowi XIII opublikowane w 1625 r. De Jure Belli ac Pacis, lecz także zbliżył się do katolicyzmu ${ }^{44}$. Co prawda w jego irenicznych

41 Polemika z Komeńskim: Jonae Slichtingii De uno omnium Deo Patre illo omnipotente et Filio ejus uno omnium Domino Christo ab ipso facto Fides antiqua contra novatores ad J. A. Comenium, Irenopoli 1685. Datacja na 28 XI 1660 w: ibidem, s. 61. Por. J. A. Comenius, Antisozinianische Schriften: Auge des Glaubens - natürliche Theologie, hrsg. von E. Schadel, P. Lang, Frankfurt/M. 2008, t. 2, s. 63-64, 109-110. M. Bečkowa, Zur Problematik der Comenius' Beziehungen zum Sozinanismus, w: Socinianism and its role in the culture of XVI-th to XVIII-th centuries, ed. L. Szczucki, PWN, Warszawa 1983, s. 169-182; M. Bečkowa, Die Brüderunität und der Antitrinitarismus, w: Faustus Socinus and his heritage, s. 215-228.

42 J. Simplicius, Notae in doctissimi cujusdam viri commentationem ad 2 caput posterioris ad Thessalonicenses Epistolae, [b.m. i druk.] 1643.

43 L. Chmaj, Hugo Grotius wobec socynianizmu, w: Id., Bracia Polscy. Ludzie, idee, wptywy, PWN, Warszawa 1957, s. 297.

44 Na temat starań o konwersję Grotiusa na katolicyzm por. A. Schubert, Kommunikation und Konkurrenz. Gelehrtenrepublik und Konfession im 17. Jahrhundert, w: 
i teologicznych pracach można było ciągle odnaleźć zapożyczenia z pism socynianów, ale dyplomata otwarcie temu zaprzeczał i polemizował z tezami Socyna i Ruara ${ }^{45}$.

Prawdopodobnie wówczas Szlichtyng przygotował także rozszerzoną polemikę z dziełem Grotiusa Votum pro pace Ecclesiastica contra Andreae Riveti et alios irreconciliabiles (1642). Ponieważ niderlandzki filozof wkrótce zmarł (1645), a sytuacja w Rzeczypospolitej stawała się dla Szlichtynga coraz trudniejsza, nigdy tej polemiki nie ogłosił i ukazała się ona wiele lat po jego śmierci ${ }^{46}$. Cały utwór miał charakter obszernego komentarza, w którym Szlichtyng odnosił się do 21 tez pracy Grotiusa, poruszając kolejno kwestie trynitologii, chrystologii, usprawiedliwienia, grzechu pierworodnego, sakramentologii, kultu świętych i stosunku do wizerunków. Wyraźnie sprzeciwił się zbliżeniu filozofa do wyznania katolickiego oraz odrzucił możliwość uznania urzędu papieża.

Wówczas, w 1644 r., Szlichtyng opublikował polemikę skierowaną przeciw Georgowi Vechnerowi (1589/1590-1647), humaniście i teologowi reformowanemu działającemu na Śląsku, a w Lesznie współpracującemu z Jednotą i Komeńskim ${ }^{47}$. Powodem było kazanie wygłoszone przez

Interkonfessionalität - Transkonfessionalität - binnenkonfessionelle Pluralität: neue Forschungen zur Konfessionalisierungsthese, hrsg. von K. von Greyerz, M. Jakubowski-Tiessen, T. Kaufmann, H. Lehmann, Gütersloher Verlagshaus, Gütersloh 2003, s. 105-131. 45 J. P. Heering, Hugo Grotius' De veritate Religionis Christianae, w: Hugo Grotius, theologian. Essays in Honour of G.H.M. Posthumus Meyjes, ed. H. J. M. Nellen, E. Rabbie, Brill, Leiden 1994, s. 41-52; Id., Hugo Grotius as apologist for the Christian Religion. A study of his work De veritate Religionis Christianae (1640), Brill, Leiden 2004; F. Mühlegger, Hugo Grotius' Auseinandersetzung mit dem Sozinianismus, w: Faustus Socinus, s. 297-326; J. Rohl, Fausto Sozzini und Hugo Grotius über die Autorität der Schrift, w: ibidem, s. 327-347.

46 Por. Jonae Slichtingii notae in Hugonis Grotii Votum pro pace, Irenopoli 1685.

47 Vechner studiował na uniwersytecie w Heidelbergu (1611), następnie we Frankfurcie nad Odrą (1617); w latach 1619-1620 był rektorem gimnazjum w Bytomiu Odrzańskim (Beuthen), gdzie, mimo posądzenia o skłonności do arianizmu, nauczał do 1628 r. Po rozwiązaniu gimnazjum przybył do Leszna, skąd powrócił na Śląsk do Brzegu, gdzie sprawował funkcję pastora i rektora gimnazjum. Por. R. Seidel, Späthumanismus in Schlesien: Caspar Dornau (1577-1631). Leben und Werk, Niemeyer, Tübingen 1994, s. 244-245, przyp. 50; Handbuch des personalen Gelegenheitsschrifttums in europäischen Bibliotheken und Archiven, hrsg. von K. Garber, T. 19 (Abteilung 4, Teil 1), Georg Olms Verlag, Hildesheim 2007, s. 37. Węgierski (por. Id., op. cit., s. 117, 380) wymienia go jako pastora we Frysztat (obecnie Karwina) w Księstwie Głogowskim, a także w Brzegu. Na temat przynależności do wyznania reformowanego por. J. S. Ehrhardt, Presbyterologie 
Vechnera w Lesznie i wydane w 1639 r., poświęcone prologowi Ewangelii św. Jana i frazie „Słowo stało się ciałem”. Vechner zadedykował je Janowi Jerzemu Szlichtyngowi, kuzynowi Jonasza, a także świeckiej elicie Jednoty $^{48}$. Jonasz Szlichtyng w polemice ogłoszonej drukiem w 1644 r. zakwestionował wnioski Vechnera na temat natur Chrystusa, koncentrując się na interpretacji terminu $\lambda$ ó $\gamma \circ \varsigma^{49}$.

W gorących miesiącach po swoim procesie i wyroku teolog nie porzucił pisania, lecz podjął dyskusję z jezuitą Mikołajem Cichowskim, atakującym braci polskich od niemal półwiecza ${ }^{50}$. W 1650 r. Cichowski ogłosił traktat, dedykowany wojewodzie lubelskiemu, Janowi Tarle, w którym krytykował ariańską interpretację prologu Ewangelii św. Jana ${ }^{51}$. Owej krytyce, sformułowanej w języku polskim, daleko było do precyzji łacińskich traktatów, zawierała ona natomiast wiele populistycznych inwektyw. W oczach Cichowskiego głosiciele nowej wiary byli „włoskimi i niemieckimi włóczęgami” oraz banitami, niszczącymi „starożytną wiary naukę" 52 . W odpowiedzi Szlichtyng opublikował w 1652 r. obronę

des Evangelischen Schlesiens, Bd. 2, Liegnitz 1782, s. 583-584. O posądzeniu o arianizm oraz teologicznym profilu szkoły w Bytomiu zob. H. Landwehr, Bartolomäus Stosch, kurbrandenburgischer Hofprediger (1604-1686), „Forschungen zur Brandenburgischen und Preußischen Geschichte”, 1898, 6, s. 91-140 (zwłaszcza s. 97).

48 Por. G. Vechner, Der Anfang des Evangelii Iohannis, von dem Worte Das das Gott War und Fleisch worden ist: Gründlich und deutlich / zu Christlicher Erbawung erklähret I Und durch eine Weinacht-Predigt / Bey der Gemeine Gottes zu Lissa in Polen / abgehandelt, [b. druk. Leszno?] 1639.

49 Por. Jonae Slichtingii de Bukowies Notae in Georgii Vechneri Concionem quam habuit super initium Evangel. Ioannis, Lesnae Anno 1639, Typis Sebastiani Sternacii, Racoviae 1644, s. 7-17. Miejsce wydania i nazwisko drukarza są fikcyjne, równolegle drukowano traktat bez miejsca i roku wydania, zapewne w Amsterdamie, por. K. Estreicher, Bibliografia, cz. 3, t. 27, s. 211; Bibliographia Sociniana, nr 2106, s. 95. Niderlandzki przekład polemiki ukazał się razem z drobniejszymi pismami Szlichtynga w: Aentekeningh en verklaringh over de ses voornaemste Schriftuurplaetsen, diemen placht te greuycken tot bewijs van de Drie-eenigheydt, en de eeuweige Godtheydt Christi, [b.m. i druk.] 1649.

50 Por. S. Radoń, op. cit., s. 23-27, 34-38, 44-58, 63-74, 81-87, 137-140.

51 Por. M. Cichowski, Wizerunek nieprawdy Aryanskiey Postrzeżoney w rozbieraniu Wyktadu na niektóre mieysca Pisma S. o Bostwie Syna Bożego, y o Troycy Przenaswiętrzey, druk. W. Piątkowski, Kraków 1650.

52 Ibidem, k. X2v-X3r (,Atoli iednak, niektorym Korony Polskiey Panom, tak do serca przypadali, ladaiacy Włoscy i Niemieccy włoczęgowie, że ich, których iako srogich bluźniercow, y Wiary ś. Krześćiańskiey z gruntu burzycielow, Oyczyste kraje wyrzuciły, za pierwsze sobie Apostoły, Wiary swey Chrześciańskiey (tak ci ludzie nową swoię wiarkę, imię krześciańskie odrzyciwszy nazywaia) obrali, y za ich powodem, starożytney wiary 
swojego wyznania wiary, do której załączył także list (Epistola Apologetica) przygotowany dwa lata wcześniej j3. W owej apologii zaznaczył, że większość zarzutów „ridendum est, non refutandum” ${ }^{54}$. Zarazem formułował postulaty dotyczące wolności religijnej, którą powinni cieszyć się także socynianie - jako obywatele Rzeczypospolitej. We własnych oczach nie był bowiem ani anabaptystą, ani arianinem, lecz chrześcijaninem ${ }^{55}$. Wyrok, który zapadł na sejmie w 1647 r., był oczywistym pogwałceniem Konfederacji Warszawskiej oraz wynikiem machinacji przeciwników Szlichtynga, którzy wcześniej doprowadzili do usunięcia go z obrad Colloquium Charitativum. Obronę Confessio fidei teolog ujął w formie komentarza do poszczególnych rozdziałów wyznania wiary, czyli kolejnych fraz Credo, rozwijając postawione tam tezy.

W 1651 r. Szlichtyng przedstawił na synodzie krótki katechizm, który był zapewne podstawą nowego wydania Katechizmu Rakowskiego, opublikowanego w 1659 r. z przedmową J. Stegmanna i A. Wiszowatego $^{56}$. Ostatnią pracą ogłoszoną za życia przez Szlichtynga była apologia skierowana do stanów Holandii i Fryzji Zachodniej w proteście przeciw antysocyniańskiemu dekretowi z 19 września roku $1653^{57}$.

Pod koniec życia Szlichtyng przestał publikować, zmuszony do częstej zmiany miejsca pobytu i zaangażowany w sprawy zborowe. Podczas potopu przybył do zajętego przez Szwedów Krakowa i wszedł w skład kolegium powołanego w celu wydania komentarza do Ewangelii św. Jana. Według świadectwa Stanisława Lubienieckiego, Szlichtyng skupił się w Krakowie

naukę, którą byli, onychże samych Przodkowie, z Pogaństwa nawróceni przyięli, przy której statecznie trwali, na ktorey się obronę, asz do podięcia śmierci, szabel własnych przy czytaniu Ewangeliey dobywaniem, gotowemi bydź oświadczali, nie tylko porzucili; ale Przodki swoie, y wszytkie Polaki, którzy żyli przed przyściem Samostatheńczyków do Polski, y rozumu y krześciaństwa odsądzili”).

53 Por. Confessionis Christianae ad rogum damnatae.

54 Jonae Schlichtingii De Bukowiec Epistola Apologetica, załącznik do: Confessionis Christianae ad rogum damnatae.

55 Por. Epistola Apologetica, s. 13-14. Por. S. Radoń, op. cit., s. 38.

56 Por. Catechesis Ecclesiarum Polonicarum, Irenopoli 1659. Szczegółowe omówienie w: A. Pfefferkorn, Jonas von Schlichting. Ein Beitrag zur Geschichte des Antitrinitarismus in Polen, R. Krahl, Bromberg 1918.

57 Por. Apologia pro veritate accusata. Ad Illustrissimos et potentissimos Hollandiae et West-Frisiae ordines. Conscripta ab Equite Polono, [b.m. i druk.] 1654. Według A. Kaweckiej-Gryczowej Apologia Szlichtynga została wydrukowana na Śląsku lub w Rzeszy (por. Ead., Ariańskie oficyny wydawnicze, s. 64-73). 
na działalności naukowej, nie angażując się w sprawy bieżącej polityki ${ }^{58}$. Prace egzegetyczne ukazały się już po śmierci Szlichtynga (1661) w zbiorze Bibliotheca Fratrum Polonorum.

Według hipotezy postawionej przez Stanisława Kota, w latach pięćdziesiątych XVII w. Szlichtyng prowadził również polemiki z Johannem Ludwigiem von Wolzogenem, rozwijając w nich poglądy na temat władzy świeckiej, wojny oraz obrony osobistej ${ }^{59}$. Dzieła te się nie zachowały i tezę o ich istnieniu oraz rekonstrukcję treści Kot oparł jedynie na replikach Wolzogena.

Pierwszy zachowany tekst będący świadectwem tego sporu wyszedł spod pióra Wolzogena i nosił tytuł Annotationes ad quatuor [!] quaestiones, de Magistratu, Bello etc. etc. quae cum his conjuncta [!] sunt ${ }^{60}$. Kot uznał więc, że dzieło Szlichtynga musiało być zatytułowane Quaestiones de magistratu, bello, defensione privata, co oczywiście nie wynika z tytułu utworu Wolzogena (zwłaszcza że mowa tam o czterech kwestiach), lecz dopiero z tytułu następnej publikacji, w którym przywołano nazwisko Szlichtynga. Ten utwór Wolzogena był „odpowiedzią na uwagi Szlichtynga do uwag na temat wojny, magistratu i prywatnej obrony" ${ }^{\prime \prime}$. Dzieło Szlichtynga musiało więc nosić tytuł Annotationes in Annotationes de Bello, Magistratu et Privata Defensione ${ }^{62}$. Mimo tradycji historiograficznej, brak

58 Por. S. Lubieniecki, Exemplum Epistolae. Por. J. Jørgensen, Lubieniecki in Kraków 1655, w: Studia nad arianizmem, red. L. Chmaj, PWN, Warszawa 1959, s. 199-202; Id., Stanistaw Lubieniecki. Zum Weg des Unitarismus von Ost nach West im 17. Jahrhundert, Vandenhoeck \& Ruprecht, Göttingen 1968, s. 37-45.

59 S. Kot, a za nim P. Brock rekonstruują argumentację Szlichtynga na podstawie dzieł jego adwersarza, Johanna Ludwiga von Wolzogena, wydanych w Bibliotheca Fratrum Polonorum. Por. S. Kot, Ideologia polityczna i spoteczna braci polskich zwanych arianami, Warszawa 1932, s. 116-124, 137, 153; P. Brock, Dilemmas of a Socinian pacifist in seventeenth century Poland, „Church History”, 1994, 63, s. 190-200 (zwłaszcza s. 197-198). Datacja na ok. 1650 r. w: S. Kot, op. cit., s. 123. Na temat Wolzogena por. K. Daugirdas, Rezeption der chronologischen und astronomischen Schriften Keplers in Johannes Ludwig von Wolzogens Evangelienkommentaren, „Barok”, 2009, 16, s. 169-191. 60 Bibliotheca Fratrum Polonorum, t. 9, s. 65-78. Kot niedokładnie przytacza tytuł dzieła Wolzogena, podając Annotationes ad Quaestiones Jonae Schlichtingii. Por. błędna informacja w Bibliographia Sociniana (s. 66), jakoby dzieło Annotationes, przedrukowane w Bibliotheca Fratrum Polonorum, było autorstwa Szlichtynga.

61 Ludovici Wolzogenii Responsio ad Jonae Slichtingii a Bucowietz Annotationes in Annotationes de Bello, Magistratu et Privata Defensione, w: Bibliotheca Fratrum Polonorum, t. 9, s. 91-132.

62 Kot przypuszcza, że tytuł brzmiał Annotationes oppositae memoratis J. L. Wolzogenii Annotationibus. 
jednoznacznych dowodów na istnienie tych dzieł. Wolzogen, co prawda, w obu utworach tytułuje swojego oponenta „autorem”, przytoczone przez niego krótkie wypowiedzi Szlichtynga mogą jednak pochodzić z prywatnej korespondencji. Ponadto ich treść nie odbiega znacznie od poglądów zawartych przez Szlichtynga w jego polemice z Meisnerem (Quaestiones duae) oraz w Apologii ${ }^{63}$. Wydaje się więc, że - wbrew sugestiom Kota utwory Szlichtynga pozostały w rękopisie, jeżeli w ogóle istniały w takiej formie, jaką sugeruje badacz.

Podsumowując rozważania nad tym okresem twórczości Szlichtynga, trzeba zauważyć, że rzadkie polemiki prowadzone w latach 1643-1661 miały zupełnie inną funkcję niż w latach 1625-1637: nie służyły już wyznaczeniu miejsca zboru ariańskiego wśród kościołów protestanckich, lecz raczej obronie przed natarczywością katolickich polemistów. Z wyjątkiem rozprawy przeciw Vechnerowi Szlichtyng nie decydował się na ich ogłoszenie lub - jak w wypadku pierwszej dysputy z Grotiusem - publikowat je anonimowo.

"To spalono, na co odpowiedzieć nie można” Scharakteryzowawszy poszczególne utwory i naturę starć toczonych przez Szlichtynga, należy przejść do ich treści, czyli systematycznego wykładu jego teologii, zastrzegając, że polemiczne wypowiedzi Szlichtynga jedynie rozwijają poglądy, których zarys można znaleźć w pismach Fausta Socyna, Walentego Smalca (Smalciusa), Jana Krella (Crelliusa), Samuela Przypkowskiego i w Katechizmie Rakowskim ${ }^{64}$. U podstaw tej refleksji stała racjonalna i krytyczna hermeneutyka przekazu biblijnego, w którym Ewangelia św. Jana zajmowała szczególne miejsce ${ }^{65}$. Szlichtyng kwestionował tradycyjną doktrynę trynitarną i chrystologiczną, modyfikował naukę o predestynacji i usprawiedliwieniu oraz bronił koncepcji wolnej woli ${ }^{66}$. W unitarystycznym duchu odrzucał koncepcję Trójcy, podporządkowując Chrystusa i Ducha Świętego jedynemu Bogu. Rozwa-

63 Responsio, s. 130; Wolzogen cytuje explicite polemikę z Meisnerem.

64 Por. L. Szczucki, Socyn Faust, w: PSB, t. 39, s. 631-636; J. Tazbir, Smalc Walenty, w: PSB, t. 39, s. 185-187. L. Chmaj, Faust Socyn, PWN, Warszawa 1963; Z. Ogonowski, Teologia naturalna Jana Crella, OiRwP, 1964, 9, s. 139-188; a także wiele innych publikacji tych autorów.

65 Na Antapologia [...] odpowiedź, s. 342 („,my Ewangelię Jana ś. jako perłe najprzednieyszą prawie pisma ś. sobie poważamy”).

66 Por. J. Jørgensen, Stanistaw Lubieniecki, s. 126-129. 
żając pojęcie boskości, sprzeciwił się rozróżnianiu osób i istoty (esencji), na czym opierała się ortodoksyjna trynitologia i chrystologia. W imię racjonalnej argumentacji odrzucał pojęcia zaadaptowane i wypracowane przez scholastykę, a przejęte przez kościoły protestanckie.

Przeciwników Szlichtynga najbardziej poruszały kwestie trynitologiczne. Teolog braci polskich od pierwszej polemiki żywo odrzucał koncepcję Trójcy jako jednego Boga w trzech osobach. Zgadzał się natomiast na użycie terminu „trójca”, jeżeli miałby on opisywać jednego Boga, jego syna, Chrystusa, będącego człowiekiem, oraz Ducha ${ }^{67}$. Duchowi Świętemu teolog odmawiał podmiotowości, uważając go za zależnego od Boga: za własność Boga, Jego tchnienie (Dei afflatus) i emanacje Jego siły (Dei Donum) $)^{68}$.

Kluczową rolę już w pierwszych polemikach odgrywała chrystologia ${ }^{69}$. Szlichtyng obszernie pisał o niej w debacie z Clementinusem (1625, 1631), ale powracał do niej w $1637 \mathrm{r}$. w trzeciej polemice z Meisnerem, w 1643 r. w debacie z Vechnerem oraz w rozprawie przeciw Grotiusowi. Najważniejszą podstawą krytyki ortodoksyjnej chrystologii był dla

67 Odpowiedź, p. 44-45 („Jeśli przez Trójcę rozumiesz Boga w trzech personach, a przecie jedynego: radzibyśmy, żeby nigdy wspominana taka Trójca nie była, a zatem nie symulujemy, żebyśmy co o niej trzymać mieli. Jeśli przez Trójcę rozumiesz Ojca, który sam tylko jest onym jedynym Bogiem, Syna, którym nikt inszy nie jest, prócz i przed człowiekiem Jezusem Christusem, i Ducha ś. który iest mocą y darem Bożym: takę Trójcę wszyscy wyznawamy”); Na Antapologia [...] odpowiedź, s. 283; Notae in Hugonis Grotii Votum pro pace, s. 1-6.

68 Por. Odpowiedź, s. 56 („Zacz my dlatego Ducha ś. z nieba sprowadzamy, że go Bogiem być nie wyznawamy, ale Bożym, jego mocą, jego darem, jako go wyznawa wszytko Pismo ś.? i zażeśmy go do mózgów swych podali, a nie raczej wy, którzyście z daru Bożego, samego Boga uczynili?”); Na Antapologia [...] odpowiedź, s. 116, 353-354; De ss. Trinitate, s. 2 („Spiritus S. denique nomine, non aliam rem ullam, qva coelestem divinumque afflatum, Dei Patris munere"), 12, 21, 36, 603-665; Notae in Georgii Vechneri Concionem, s. 88-89; De uno omnium Deo, s. 36-37; J. Szlichtyng, Reverendi viri D. Nicolai Cichovii. Societatis quae Iesu nomen praefert. Centuria argumentorum caesa, b.m. 1652, s. 7-8 („Spiritus S. itidem nomine nobis significatur, et in scripturis significari a nobis afferitur, caeleste illud Dei Donum, quo sancti homines a Deo afflantur et sanctificantur, quod ipsum summum Deum esse quis dixerit”); Id., De Fide primorum Christianorum, Martyrum \& veterum Patrum, w: De Uno omnium Deo, s. 17 („Spiritus nimirum \& afflatus Dei Sanctissimus, Virtus Dei \& Donum singularissimum”). Por. J. Jørgensen, Stanistaw Lubieniecki, s. 130.

69 Polemiki poprzedzające działalność Szlichtynga scharakteryzowano w: J. Misiurek, Spory chrystologiczne w Polsce w drugiej potowie XVI wieku, KUL, Lublin 1984. 
Szlichtynga przekaz Ewangelii św. Jana. Szlichtyng dowodził, że Janowy $\lambda$ ójo - co zgodnie z Erazmiańską tradycją należy przekładać jako „sermo”, a nie „verbum” - odnosi się do Chrystusa, który po wcieleniu był jednorodnym synem Boga. Był on jedynie człowiekiem, poczętym przez Ducha Świętego i urodzonym przez kobietę o imieniu Maria ${ }^{70}$. Odpierając zarzut negowania bóstwa Chrystusa, Szlichtyng wytykał Clementinusowi, Vechnerowi i Cichowskiemu, że tradycyjna chrystologia negowała ludzką naturę Chrystusa, a przecież męka, śmierć, wniebowstąpienie i obietnica powtórnego przyjścia odnosiły się do człowieka, a nie do nieśmiertelnego i wiecznego Boga ${ }^{71}$. Jak zauważył Szlichtyng, przypisywanie Bogu ludzkich zachowań i emocji było zgodne z luterańską wykładnią koncepcji communicatio idiomatum, której teolodzy reformowani zazwyczaj nie akceptowali ${ }^{72}$.

Zarazem jednak Szlichtyng chętnie przyznawał, że Chrystus był Bogiem. Pojęcie „bóstwa” rozumiał jednak inaczej niż jego adwersarze. Sam fakt poczęcia z Ducha Świętego wystarczał, aby nazwać Chrystusa

70 Por. De ss. Trinitate, s. 2 („Nos vero, solius Patris nomines summum illum unicumque Deum rerum omnium conditorem, significari debere dicimus: Filii vero nomine, non alium vllum, quam Iesum Christum hominem, ex Spiritu S. conceptum, \& ex virgine natum Maria"), 7, 11, 21, 435; Commentarius in Euangelium Joannis Apostoli, w: Bibliotheca Fratrum Polonorum, t. 3, s. 4 („,Homo est homo, non aliud aliquid, substantiae suae respectu, multo vero minus, divina ante mundum existens persona. Homo excludit omnia quae sunt non homo").

71 Por. Odpowiedź, s. 3 („niemasz nic prawdziwszego nader wywyższył y na prawicy swoiey posadził, ale tego który był posłusznym aż do śmierci, a śmierci krzyżowey: nie Bogu przedwiecznemu wszytkie rzeczy pod nogi poddał, ale nad Anioły nieco umnieyszonemu niekiedy: nie Boga przedwiecznego czcią y chwałą ukoronował, ale tego który śmierć ucierpiał; nie Boga przedwiecznego sędzią żywych y umarłych postanowił, ale męża od umarlych obudzonego: nie Boga przedwiecznego ofiarownikiem wiecznym przełożył nad domem swoim, ale tego który z krzykiem silnym y zełzami niekiedy prośby swoie ofiarował tego który go mogł z śmierci wybawiać"); De ss. Trinitate, s. 47-48 (nota na marginesie: „Omnia divinitatis de Filio Dei elogia recte ad ipsam humanam Christi naturam referri possunt"); Notae in Georgii Vechneri Concionem, s. 17-18; Confessionis Christianae ad rogum damnatae, s. 101-104.

72 Por. Na Antapologia [...] odpowiedź, s. 341 („«Wszytko to, pisze [Clementinus - M. P.], Bogu przystoi, i rodzić, i rodzić się, Synem być, i człowiekiem być, umrzeć, krew wylać, i zmartwychwstać, blizny wciele swoim mieć, i do nieba wstąpić». Już-że było i tego dołożyć, że i to na Boga przystoi, aby Bogiem nie był, bo tam to, tym pachnie $[\ldots]$ a wżdyć $\mathrm{i}$ według was tak człowiek stał Bogiem, jako i Bóg człowiekiem per communicatio idiomatum?"). Por. B. Meisner, Disputatio VII. De Tertio Genere Communicationis Idiomatum, Johan Gormann, Wittebergae 1614. 
synem Bożym ${ }^{73}$. Dalej głosił, że Chrystus miał status „średniego Boga”, pośredniczącego między jedynym Bogiem, a innymi istotami boskimi ${ }^{74}$. W istocie bowiem Szlichtyng kwestionował koncepcje współistotności

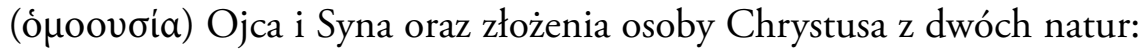
ludzkiej i boskiej ${ }^{75}$. Polemika z Grotiusem, która ukazała się po śmierci Szlichtynga, zawiera jednak radykalniejsze sformułowanie, głoszące, iż Chrystusa zwie się panem, a nie Bogiem, aby uniknąć posądzenia o politeizm: ,ideo eum [=Christum] Dominum non Deum hic appellamus, ut appareat nos duos non statuere Deos"76.

Konsekwencją tego stanowiska było zakwestionowanie preegzystencji Chrystusa: „My Christusa prawdziwym Bogiem być wyznawamy, choć nie przedwiecznym" ${ }^{\prime 7}$. O fragmentach Ewangelii Janowej (J 3,13; J 6,62), mówiących o uprzednim pobycie Chrystusa w niebie i jego zstąpieniu, Szlichtyng utrzymywał, że odnoszą się do epizodu z biografii Chrystusa, który jeszcze za życia został przyjęty przez Boga, po czym powrócił na

73 Por. De ss. Trinitate, s. 11, 58; Notae in Georgii Vechneri Concionem, s. 17-20; Apologia pro veritate accusata, s. 10-11.

74 Por. Odpowiedź, s. 12 („Prawda to, że słówko to Boga, Chrystusowi w śrzednim nietakim znaczniu między onym naywyższym Bogiem, a między inszemi prawdziwemi Bogami należy, z tey miary; że Pan Christus to ma spolnego z Bogiem naywyższym że mu iest rownym w mocy y zwierzchności nad wszytkiemi rzeczami; a z ziemskiemi y niebieskiemi Bogami, że te władzą, moc y panowanie swoie, iako y oni, wziął od Boga onego iedynego z łaski iego"). Por. De ss. Trinitate, s. 158.

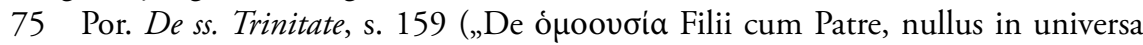
Scriptura exstat locus. Consequentiis autem in re tam gravi, praesertim contra apertam rationem agere, temeritas est"), 596-599; Confessionis Christianae ad rogum damnatae, s. 109.

76 Notae in Georgii Vechneri Concionem, s. 167. Podobnie w: De uno omnium Deo, s. 34-35.

77 Odpowiedź, s. 169-170. Por. także: Na Antapologia [...] odpowiedź, s. 7 („O czym namniejszej wzmianki w tym Credzie nie masz, w którym samego tylko Ojca, Bogiem y Stworzycielem wyznawamy, a Pana Jezusa Synem tego Boga i stworzyciela jedynym, takim, który się począł z Ducha świętego i z Panny narodził ec. Gdzie tu przedwieczność Syna Bożego? Gdzie wtóra abo y trzecia osoba w bostwie?”), 154 („Jeśli Christus rzeczą samą względem Boskiej natury i osoby był przed założeniem świata, czemu tak po prostu o nim mówi Piotr święty, że był przed założeniem świata przeznany, a zatym że jeszcze rzeczą samą przed założeniem świata nie był?”); De ss. Trinitate, s. 2 („non spectatam in eo [=in Christo - M. P.] aliam vllam, per quam iam ante Deus fuerit, hominemque induerit, naturam"), 146-147. 
ziemię $^{78}$. Stanowisku negującemu preegzystencję Chrystusa pozostawał wierny w całej twórczości, lecz bywało, że w zapale polemicznym formułował opinie, które jej nie wykluczały. W debacie z Vechnerem, broniąc poglądu, że $\lambda o ́ \gamma o \varsigma$ w prologu Ewangelii Janowej odnosił się do Chrystusa, zakładał hipotetycznie, że „Christum aliam, antequam nasceretur, naturam habuisse" 79 .

Ustalenia w zakresie chrystologii były ważne ze względu na ich rolę w nauce o usprawiedliwieniu, ponieważ usprawiedliwienie człowieka, co Szlichtyng chętnie przyznawał, jest możliwe dzięki ofierze Chrystusa oraz wierze. Uważał jednak, że podkreślanie wyłącznie zasługi Chrystusa, głoszenie koncepcji usprawiedliwienia przez wiarę oraz predestynacji odbierało podstawę ludzkiej pobożności. Dlatego odrzucał koncepcję usprawiedliwienia przypisującą człowiekowi zasługi Chrystusa („iustitia imputativa”). Była ona według niego sprzeczna z ideami sprawiedliwości oraz boskiego miłosierdzia ${ }^{80}$. Co więcej, pozbawiała ludzi motywacji do prowadzenia pobożnego życia ${ }^{81}$. Krytykował także Anzelmiańską koncepcję usprawiedliwienia jako zadośćuczynienia („satisfactio”) dzięki ofierze złożonej przez Chrystusa ${ }^{82}$. Jakakolwiek forma satysfakcji była sprzeczna z obietnicą usprawiedliwienia gratis ${ }^{83}$. Co więcej, przyjęcie („apprehensio”) zasług Chrystusa było także aktywnością, a więc dobrym uczynkiem

78 Por. Odpowiedź, s. 71 („Albowiem sam Pan mówił, że syn człowieczy wstąpił do nieba, i zstąpił z nieba, i że był w niebie”); Na Antapologia [...] odpowiedź, s. 208; De ss. Trinitate, s. 7; Commentarius in Euangelium Joannis Apostoli, s. 4-5, 27-28, 53. Por. S. Radoń, op. cit., s. 65; J. Jørgensen, Stanistaw Lubieniecki, s. 145.

79 Notae in Georgii Vechneri Concionem, s. 20. W dalszym wywodzie Szlichtyng odrzuca tę hipotezę (por. ibidem, s. 67, por. s. 69, 76-78, 150-151 oraz De Fide primorum, s. 22). 80 Por. Na Antapologia [...] odpowiedź, s. 104.

81 Por. Odpowiedź, s. 11 („Która nauka nie tylko w ludziach chęć do wszelakiey pobożności gasi, ale też Boga niesprawiedliwym czyni”); Na Antapologia [...] odpowiedź, s. 63, 75-80; Quastiones dua, s. 136-137, 212, 241-290; Apologia pro veritate accusata, s. 70-71.

82 Por. Odpowiedź, s. 9 („Cosz po tey conditiey wierzenia, ieśli Bogu prawdziwie zapłacono? y owszem nie może być ta conditia przydana, boby za tym szło że oraz y dosyć uczyniono y nie uczyniono, bo zostanie conditia: a zaś dosyć uczyniono: bo temu mocno wierzyć mamy”), 12, 75; Na Antapologia [...] odpowiedź, s. 332; Quastiones dua, s. 288-289.

83 Por. Quastiones due, s. 136-137 („At vero, Meisnere, si Christi justitia nobis imputatur, quid opus est, ut imputetur satisfactio pro poena, quia omnia nostra peccata, et commissionis, et omissionis, ablata sunt, quid opus est ut imputetur justitia?"), 212-242; De ss. Trinitate, s. 825-827. Por. J. Jørgensen, Stanistaw Lubieniecki, s. 152-153. 
(„bonum opus”), co także kłóciło się z koncepcją usprawiedliwienia przez wiarę $^{84}$. Bliższa Szlichtyngowi była natomiast koncepcja egzemplaryczności męki i śmierci Chrystusa, rozwinięta przez Piotra Abelarda i Bernarda z Clairvaux, choć także za nią opowiadał się niejednoznacznie ${ }^{85}$.

Clementinus w swojej polemice zaatakował sformułowanie użyte przez Socyna, iż śmierć Chrystusa była jedynie „metaforyczną zapłatą” („metaphoricum pretium”, „redemptio metaphorica”). Szlichtyng bronił terminu Socyna, podkreślając, że terminy „zapłata” czy „wykup” nie mogą być rozumiane wprost, gdyż ani nikomu za nic nie płacono, ani krew nie jest żadnym płacidłem. Także cały przekaz o męce Chrystusa miał dla Szlich-

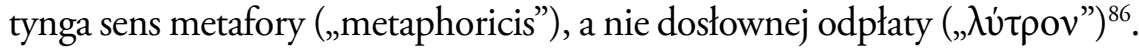

Dyskusja nad usprawiedliwieniem oraz rolą Chrystusa prowadziła nieodmiennie do pytania o predestynację oraz zdolność człowieka do wpływania na swoje zbawienie. W polemice z Clementinusem Szlichtyng wypowiadał się bardzo zdecydowanie przeciw koncepcji podwójnej predestynacji, zarówno do zbawienia, jak i do potępienia ${ }^{87}$. W debacie z Meisnerem próbował tę koncepcję adaptować, łącząc ją z (filipistycznym, semipelagiańskim czy jezuickim) przekonaniem o udziale ludzkiej woli w dziele zbawienia. Przedwieczny boży wybór jest bowiem in genere nieodmienny, in individuo jednak - zmienny ${ }^{88}$. Przed- i wszechwiedza Boga była podstawą jedynie „ograniczonej predestynacji”»" liczba zaś

84 Por. Quastiones dua, s. 291-293.

85 Por. ibidem, s. 214 („Hic similiter video, cum Christi morte conjungi nostram pietatem, sed eam cum Christi merito et satisfactione conjugi non video").

86 Por. ibidem, s. 228, 247; Odpowiedź, s. 14, 141-142 („Nie pojął tego X. Clement, co Socin per redemptionem metaphoricam rozumie, gdyż nie to mówi Socin, żeby wybawienie i zbawienie nasze było niewłasne i metaphoriczne, ale że to własne, istotne i prawdziwe wybawienie, metaphorice i niewłaściwie wykupieniem jest nazywane, a to dlatego, że nie masz tego, któryby zapłatę brał"); Na Antapologia [...] odpowiedź, s. 62 („Homine imperito, ktoś powiedział, nihil injustius. Czy to nie wiecie, że nas Pan Bóg, abo Pan Jezus, krwią własną kupił? Czy tam jest własne kupno, kedy co krwie przelaniem kupuią? Czy bierze kto tę krew?"); Confessionis Christianae ad rogum damnatae, 127-129 („Metaphora quidam est in Redemptionis voce: at maxima veritas et proprietas est in ipsa re").

87 Odpowiedź, s. 10 („Która nauka nie tylko w ludziach chęć do wszelakiey pobożności gasi, ale też Boga niesprawiedliwym czyni”); Na Antapologia [...] odpowiedź, s. 101-106, 385-398.

88 Por. Quastiones due, s. 16, 119.

89 Ibidem, s. 30 („non absolutam, sed conditionatam praedestinationem”); Notae in Hugonis Grotii Votum pro pace, s. 158-159. 
wybranych była otwarta i zmienna ${ }^{90}$. Człowiek mógł bowiem łaskę bożą zarówno przyjąć, jak i odrzucić ${ }^{91}$. Dlatego w dziele usprawiedliwienia nie pozostaje biernym obiektem działalności Ducha Świętego (jak słup czy kamień), lecz podejmuje wolną decyzję o słuchaniu Słowa: „Jest-ci wiara dar Boży, ale przecież kto ją ma od Boga, dobrowolnie ją wziął, i kto jej nie ma, choć mu ją dawano, brać jej dobrowolnie nie chciał"92. Nawrócenie jest dziełem Bożym o tyle, o ile to Bóg dał człowiekowi oczy, uczy, rozum i wolę, a więc umożliwił w ogóle powstanie sytuacji wyboru $^{93}$. Luteranie (jak Meisner) negowali w tej sytuacji wolność woli

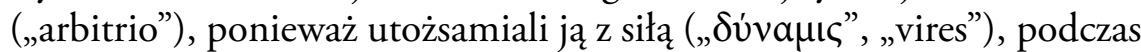
gdy dla Szlichtynga istotą arbitrio był sam akt woli (chcę - nie chcę) $)^{94}$. Pytanie nie dotyczyło więc możliwości działania, lecz pragnienia.

W rzeczy samej, Szlichtyng pragnął ukazać spór o łaskę jako konflikt o wizję człowieka. Meisner miał pesymistycznie twierdzić, że przed nawróceniem człowiek nie potrafi chcieć usprawiedliwienia, a po nawróceniu - nie może go nie pragnąc ${ }^{95}$. Temu stanowisku przeciwstawiał Szlichtyng optymistyczną antropologię, zgodnie z którą człowiek był istotą racjonalną, zdolną kierować afektami przy pomocy własnego rozumu ${ }^{96}$. Racjonalny, czyli poznawalny i zgodny z rozumem, był także przekaz

90 Por. ibidem, s. 38 („electorum numerum non fore certum et infallibilem, sed, prout mutantur homines, mutabilem").

91 Por. ibidem, s. 30-36, 71-72; Notae in Hugonis Grotii Votum pro pace, s. 29.

92 Por. Na Antapologia [...] odpowiedź, s. 83-88, cyt. 83; Quaestio, s. 41-42 („Non ergo Deus sic homines indurat, ut ad eum converti nullo modo possint, sed difficilem tantum \& impeditum ad se accessum illis, cum merentur, facit, ut simul \& puniat eos, et tamen virtuti eorum locum relinquat, si forte, tantas difficultates et impedimenta emoliti, ad Deum accesserint”); Questiones dux, s. 63 („libere tamen velle possumus, ac nolle possemus"); Apologia pro veritate accusata, s. 26.

93 Por. Quastiones due, s. 67 („Verum quatenus haec omnia nullo pacto facere possemus, nisi Deus et naturae facultatem, nisi aures, oculos, intellectum, voluntetem, os, manus, et reliqua membra nobis dedisset, et praeterea nisi nos vocasset, ac ad se invitasset, verbum suum nobis praedicari, illudq. omnibus modis confirmari curasset; hactenus conversionem nostram soli Deo in solidum attribuere debemus").

94 Por. ibidem, s. 87 („Arbitrium, Meisnere, non sunt vires: sed est ipsum velle et nolle, eligere aliquid et repudiare. Hoc liberum dicimus, cum aeque licet aliquid et velle et nolle, eligere et repudiare; servum cum nonnisi alterutrum licet”).

95 Por. ibidem, s. 88.

96 Por. Quaestio, s. 20-21; Quastiones dua, s. 88-89 („Nos semper liberum et velle et nolle, sive ante conversionem, sive in conversionem, sive post conversionem homini esse dicimus, ut et virtuti ac vitio, et praemiis ac poenis locum relinquamus"). 
biblijny ${ }^{97}$. Co więcej, chrześcijanie nie powinni dawać wiary dogmatom, które stałyby w sprzeczności z nakazami rozumu ${ }^{98}$.

Sama wiara nie była bowiem (jedynie) darem, lecz woluntarystycznym aktem $^{99}$, opartym na poznaniu i racjonalnej decyzji ${ }^{100}$. Szlichtyng celowo zacierał różnicę między „fides” (darem Bożym) a „fiducia” (zawierzeniem Bogu ${ }^{101}$. Cytując zaś definicję wiary podaną przez Socyna ${ }^{102}$, Szlichtyng proponował, aby ująć pojęcie wiary możliwie najszerzej, jako metonimię całego procesu zbawczego ${ }^{103}$.

Owa obrona koncepcji wolnej woli i możliwości (oraz konieczności) wyboru, dokonywanego przez człowieka, pociągała za sobą uznanie znaczenia ludzkich uczynków dla usprawiedliwienia. Dlatego Szlichtyng sprzeciwił się radykalnej opozycji Ewangelii (łaski) i Prawa, którą głosił Meisner. Przyznawał, że Prawo wymagało uczynków, a Ewangelia - wiary, ale uważał, że również wiara musiała być „żywa” ${ }^{104}$, to znaczy powinna

97 Por. De ss. Trinitate, s. 66 („Illud libenter agnoscimus, Scripturam nihil nobis credendum proponere, quod sensui communi et apertae rationi repugnet, seu contradictionem manifestam contineat”), 68-70 („quomodo enim alioquin illis credet, nisi prius de eorum veritate judicaverit?").

98 Por. ibidem, s. 75 („Non ergo nobis imaginari talia in Christi religione dogmata debemus, quae rectae rationis examen judiciumque refugiant”), 123 („Quidquid autem nobis revelatum est, quidquid a nobis credi debet, id nequaquam rationis captum excedit, vel excedere potest. Unde apparet, nihil esse in Theologia, quatenus quidpiam revelatum est aut credi debet, de quo ratio recta judicare non possit, imo non debeat"), 136-137; Confessionis Christianae ad rogum damnatae, s. 5 („Dogma humanae menti inaccessum, relinquamus").

99 Por. Quastiones due, s. 22 („Fides enim nostra tum, cum Deus occasionem et causam credendi nobis suppeditat, voluntarium est opus").

100 Por. De ss. Trinitate, s. 78 („Nec enim sine ratione ac judicio Dei verbo crediderant. Cur enim crediderunt? nempe quia Deus dixit. At hoc ipsum, quod Deus sit; quod Deo credendum sit; quod Deus hoc dixerit; nonne prius ratio et intellectus ex certis causis et argumentis conclusit?”), 125 („Diximus enim paulo ante, nihil credi posse quod a ratione capi et intelligi nequeat. Nam fides in assensu consistit; assensus judicium sequitur; judicium autem de re ignota et non intellecta nullum est").

101 Por. Quastiones dua, s. 304-305.

102 Por. F. Socyn, Quod regni Poloniae, s. 696.

103 Por. Questiones due, s. 313.

104 Por. Quaestio, s. 11-12 („Nec enim Evangelium nuda fide contentum est, sed per charitatem efficaci, sed viva, seu tali, quae bonis operibus sit animata, alioquin ad justificationem nihil profutura”); Quastiones dua, s. 139-140 („Adde, quod, si id agnoscis, nos per fidem non mortuam, sed vivam iustificari; agnoscere etiam debeas, nos 
pociągać za sobą pokutę i przemianę życia ${ }^{105}$. W innym miejscu, powołując się na Augustyna, Szlichtyng utrzymywał, iż predestynacja dotyczyła nie tylko życia wiecznego, lecz także dobrych uczynków ${ }^{106}$. Podkreślając znaczenie predestynacji, chciał Szlichtyng uniknąć wrażenia, iż to ludzkie uczynki ze względu na swoją godność są przyczyną zbawienia - ostatecznie bowiem byłyby one niczym bez łaski.

Takie ujęcie kwestii ludzkiego działania i wolnej woli było dla Szlichtynga fundamentem zarówno sprawiedliwości bożej, jak i moralności oraz pobożności ludzkiej. Wynikało także z negowania znaczenia grzechu pierworodnego, który był występkiem Adama, ale nie obciążał jego potomków ${ }^{107}$. Ludzie odczuwali od urodzenia większą skłonność do zła, wynikała ona jednak nie z piętna grzechu, lecz z ich „natury” oraz „popędów ciała” 108 .

Warto zaznaczyć, że w porównaniu do powyższych, bardzo abstrakcyjnych kwestii Szlichtyng stosunkowo rzadko poruszał problemy sakramentologii, wiążące się z praktycznymi zagadnieniami liturgii. Nie uważał również za niezbędne wypowiadać się obszernie na tematy wystroju kościołów. Ilekroć to robił, pozostawał w ramach ortodoksji reformowanej, wyznaczanej przez pisma Teodora Bezy, Henryka Bullingera i Jana Kalwina.

non sola fide ab omnibus operibus seiuncta, sed cum operibus coniuncta, iustificari"), 158, 325-332; De ss. Trinitate, s. 51-53.

105 Por. Quaestio, s. 32, 38; Quastiones dua, s. 133-134 („Iustificatio enim nec incipit sine fide ac poenitentia; nec durat sine fidei poenitentiaq. fructibus atque effectis”), 215. 106 Por. Quastiones due, s. 13 („Caeterum Augustinus in hoc dicto expresse asserit, Deum praedestinare homines non tantum ad vitam aeternam, quod solum volunt Lutherani, sed etiam ad bona opera, seu vitae aeternae consequendae media, ut volunt Calviniani. Unde apparet, et Augustinum cum Calvinianis facere, quod infra negat Meisnerus; et Meisnerum inconstanter Calvinianis objicere, quod eorum praedestinatione tollatur omne bonorum operum studium").

107 Por. Confessionis Christianae ad rogum damnatae, s. 191-194.

108 Por. Odpowiedź, s. 59-60 („Rodzą się ludzie [...] ani złemi ani dobremi, a zatym ani świętymi ani przeklętymi, to prawda, że do grzechu niż do cnoty skłonniejszymi, ale ta skłonność do grzechu sama przez się nikogo złymi nie czyni (jako i z drugiey strony skłonność do cnoty cnotliwymi) i nie z grzechu Adamowego pochodzi, ale stąd, że grzech ciału smaczny, a cnota przykra, y że ludziom consuetudo peccandi pene abiit in naturam, której się potym i potomstwu dostawa [...] prawda, że tego grzechu neguiemy, ale żebyśmy to contra veracissimas scripturae assertiones czynili, a zatym sine fronte, rzec mogę, że to potwarz sine fronte"); Na Antapologia [...] odpowiedź, s. 366-367. 
Wykład znaczenia sakramentu eucharystii był bardzo bliski reformowanej ortodoksji: eucharystia była dla Szlichtynga znakiem lub symbolem („memoriale signum” ${ }^{109}$, a zarazem instrumentem bożej łaski ${ }^{110}$. Teolog odrzucał koncepcję realnej obecności ciała (ludzkiej natury) Chrystusa w sakramencie. Explicite sprzeciwiał się zarówno głoszonej przez katolików transsubstancjacji, jak i luterańskiej konsubstancjacji ${ }^{111}$. Słowa ustanowienia (słynne „hoc est corpus meum”) uważał za metaforę ${ }^{112}$. Również koncepcja ubikwitarystyczna - wedle której realne ciało Chrystusa jest wszechobecne, a więc występuje także w Eucharystii - była według niego absurdalna ${ }^{113}$. Uczta eucharystyczna miała znaczenie jedynie duchowe, była „pamiątką” i „znakiem” ${ }^{114}$. Dlatego uczestnictwo w niej nie było obowiązkowe - skoro ryt nie był niczym więcej niż pamiątką, uczestnictwo

109 Por. De ss. Trinitate, s. 701-707, 789 („Verum cum panis proprie loquendo non possit esse corpus Christi, sed tantum signum corporis Christi, propterea etiam proprie loquendo non edimus corpus Christi, sed figuram et signum corporis Christi. Ad figuram corporis Christi edere et ipsum corpus Christi edere diversissima sunt. Imo si ipsum Christi corpus ederemus, quid attineret panem illius figuram edere?"); Notae in Hugonis Grotii Votum pro pace, s. 23, 112, 126, 138 (,itaque nego sub panis istius \& calicis ut loquuntur speciebus quicquam aliud esse quam signum memoriale corporis \& sanguinis seu mortis Christi: quas propterea falsum est efferri, cum signa memorialia Deo offerri non solerent, nec illorum ratio quicquam cum oblationibus commune habeat"); Apologia pro veritate accusata, s. 29.

110 Por. Notae in Hugonis Grotii Votum pro pace, s. 47 („Sacramenta non tantum signa esse acceptae, sed etiam instrumenta per quae Deus operatur, dando \& augendo gratiam, verum est, si recte explicetur").

111 Por. De ss. Trinitate, s. 707-709; Notae in Hugonis Grotii Votum pro pace, s. 119 („Vir iste Doctissimus cum vulgarem Catholicorum Transsubstantiationem atque Lutheranorum Consubstantiationem (utamur enim barbaris vocibus, quando in eo Ecclesiae tempore incidimus) merito improbaret; eorum autem qui se Reformatos vocant, sententiam ad voces \& loquendi formas Catholicis usitatas accommodare vellet, Apostolicae doctrinae viam deseruit, \& frustra pacem atque conciliationem Ecclesiae: quae nunquam nisi tradita ab Apostolis veritate, vera $\&$ stabili concordia uniri poterit. Multa enim $\&$ ambigue $\&$ adeo sive subtiliter sive obscure dixit, ut in Christiana simplicitate nullum habeant usum").

112 Por. De ss. Trinitate, s. 709-712, 731-732.

113 Por. Notae in Hugonis Grotii Votum pro pace, s. 21 („Cum autem evidenter sit absurdum \& contradictionem implicet humanam Christi naturam ubique esse”).

114 Por. ibidem, s. 25-26 („Est igitur corpus Christi quod nunc habet, vivum, spirituale $\&$ incorruptibile, vere, reipsa, substantialiter \& proprie in supremo coelo: Corpus Christi mortuum \& ex sangvine effuso, spiritualiter est in iis qui corpus hoc edunt, $\&$ sangvinem bibunt, spirituali nimirum ratione, seu quae spiritu fiat non corpore [...] 
lub absencja wiernego nie miała żadnego wpływu ani na stan kościoła, ani na kondycję chrześcijanina ${ }^{115}$.

Znaczenie sakramentu jako „instrumentu łaski” było przez Szlichtynga szczególnie podkreślane w przypadku chrztu. Miał on być nie tylko znakiem odpuszczenia grzechów, lecz także „środkiem” (medium) ${ }^{116}$. Warunkiem chrztu była świadomość prawd wiary, co wymagało od chrzczonego pewnej dojrzałości - zarówno umysłowej, jak i duchowej ${ }^{117}$. Ponieważ dzieci jej nie miały, Szlichtyng krytykował pedobaptyzm ${ }^{118}$. Ponadto, chrzest mógłby być zagrożeniem dla zdrowia dziecka, gdyż winien odbywać się nie przez pokropienie (aspersio), lecz przez zanurzenie całego ciała (immersio) ${ }^{119}$. Mimo to w polemikach z Meisnerem i Grotiusem Szlichtyng nie potępiał chrztu dzieci, uważając, że można ten błąd w kościele tolerować ${ }^{120}$.

Dość tolerancyjny był także stosunek Szlichtynga do kultu świętych i Marii. Informacje o ich życiu i ich cudach na ziemi uważał za wiarygodne, jeżeli pochodziły z pewnego źródła. Relikwiom świętych (kościom, chustom czy nawet cieniom) należało okazać szacunek. Mogły czynić cuda - podobnie jak Bóg sprawił, że oślica przemówiła ${ }^{121}$. Jednak nic nie wiadomo o bytowaniu świętych w niebie, podobnie jak o ich pośrednictwie ${ }^{122}$. Dlatego cześć okazywana świętym i relikwiom powinna polegać na złożeniu ich w bezpiecznym miejscu, a nie na zabobonnych praktykach ${ }^{123}$. Katolickie rozróżnienie między „dulia”

In ritu autem Eucharistico non aliter est corpus \& sanguinis Christi, quam quatenus illius memoriale signum ritus iste continet").

115 Por. ibidem, s. 140-141.

116 Por. ibidem, s. 47-48.

117 Por. De ss. Trinitate, s. 853-854; Notae in Hugonis Grotii Votum pro pace, s. 105-106.

118 Por. De ss. Trinitate, s. 844-845 („Infantes autem capaces esse negamus”).

119 Por. ibidem, s. 853-856 („Urgemus denique ipsum baptismi ritum, qui totius hominis immersione in aquam, non levi verticis aspersione continetur [...] Baptismum vero immersionem totius hominis esse").

120 Por. ibidem, s. 831 („Errorem quidem hunc esse, eumque sat gravem, praesertim si infantium baptismus ad salutem necessarius esse statuatur, dicimus; sed nequaquam ita gravem, ut in Ecclesia tolerari prorsus non debeat"); Notae in Hugonis Grotii Votum pro pace, s. 105 („Ideo nec eos qui infantes baptizant, damnare audemus”).

121 Por. Notae in Hugonis Grotii Votum pro pace, s. 191. Por. uwagi na temat niepokalanego poczęcia w: De ss. Trinitate, s. 91.

122 Por. Notae in Hugonis Grotii Votum pro pace, s. 162-164.

123 Por. ibidem, s. 191-192 („Honorentur ergo Sanctorum (nam umbra certe Petri non superfuit) reliquiae, id est eo se ponantur loco, qui nec profanis usibus, nec superstitionibus pateat"). 
a „latria”, którego bronił, między innymi, Cichowski, było bezsensowną zabawą słowną ${ }^{124}$.

Bardziej radykalnie wyrażał się Szlichtyng na temat wizerunków. Bóg zakazał tworzenia wszelkich podobizn: „simulachra seu sculptilia, sed etiam omnem assimilationem" ${ }^{125}$, sam Bóg jest bowiem niepoznawalny zmysłami śmiertelników, a wszelkie przedstawienia skłaniają do nieprawdziwego kultu ${ }^{126}$. Jednocześnie Szlichtyng przyznawał, że sztuka świecka jest w pełni dozwolona, służy podtrzymaniu pamięci i budzi zachwyt dla zręczności rąk i talentu. Co więcej, zaznaczał, że Salomon słusznie umieszczał wizerunki w świątyni ${ }^{127}$. Innymi słowy, zakaz wizerunków odnosił się do kultu, a nie do tworzenia wszelkich przestawień, obrazy i rzeźby zaś - jako „memoria” - nie były złe same w sobie, niewłaściwy mógł być jedynie czyniony z nich użytek lub przypisywane im znaczenie ${ }^{128}$.

$\mathrm{Na}$ zakończenie rekonstrukcji poglądów Szlichtynga należy poruszyć kwestie najbardziej kontrowersyjne, czyli stosunek do urzędów (kościoła i państwa), dyscypliny, władzy świeckiej, a także jednostki. Problem ten jest bardzo złożony, dotyka bowiem trzech zagadnień: definicji urzędu i wynikających z niej teoretycznych prerogatyw; praktycznego zakresu władzy, powstającego w wyniku konfrontacji teorii i praktyki; a także sytuacji chrześcijanina.

Kościół był, wedle Szlichtynga, wspólnotą wiernych, na której czele stał Chrystus i w której obrębie panowała równość. Ecclesia nie była społecznością ziemską, lecz boską, więc nie powinna rządzić się ziemskimi prawami ${ }^{129}$. Oczywiście, istniały w owej wspólnocie urzędy, ale

124 Por. Confessionis Christianae ad rogum damnatae, s. 51 („Non divino, inquis, nec latriae, sed duliae cultu. quid nos ludis vocibus? dulia et latria Synonyma sunt Graecis, eamque serviendi voce in aliis linguis redduntur [...] Itaque cum in cultu ad religionem spectante distinguis, nun latriae, sed duliae, perinde est, ac si diceres, non latriae sed latriae, non duliae sed duliae; quod est nugari”).

125 Notae in Hugonis Grotii Votum pro pace, s. 192.

126 Por. ibidem, s. 193-194.

127 Por. ibidem, s. 192 („Probe id intellexit sapientissimus mortalium Salomon, qui $\&$ in Regia sua, \& in Dei templo varia posuit simulachra”).

128 Por. ibidem, s. 201 („Imagines sive sanctorum sive profanorum memoriae tantum, \& ejus qui memoria continetur honoris, causa ponere, nullum in se crimen habet. Flexu autem corporis, aut alio aliquo signo, ostendere, apud se in honore esse eum, cujus ea est imago, si id tanquam coelesti menti fiat, res humanas, quamvis iis exemta sit, curanti, Idolatria est").

129 Por. ibidem, s. 153 („Ecclesia non est societas humana, sed divina; ideoque nullis aliis legibus gubernari debet quam divinis, \& ab ipsa sanctitate dictatis"); Confessionis Christianae ad rogum damnatae, s. 187-189. 
ich utworzenie nie prowadziło do powstania hierarchii i stosunku bezwzględnego podporządkowania. Zwierzchnicy, prepozyci - pozostawali tylko funkcjonariuszami, a nie panami ${ }^{130}$. Ministrowie Słowa powinni głosić pokój, a nie wojnę, nie zostali bowiem powołani do rządzenia, lecz do troski o sprawy religii. Szlichtyng określat ich czasem terminem „kler”, zaznaczał jednak, że używał tego słowa tylko w sensie technicznym, ponieważ w kościele nie było podziału na świeckich i duchownych ${ }^{131}$. Wierni mieli prawo do nieposłuszeństwa w sytuacji, gdy zwierzchnicy łamali przyjęte normy ${ }^{132}$. Nowości wprowadzone przez rzymski kościół, gwałcące „duchową wolność i godność wiary”, już dawno powinny zostać usunięte ${ }^{133}$.

Szlichtyng wielokrotnie w swoich polemikach wypowiadał się w obronie "godności wiary" i tolerancji. Odrzucając potrzebę dyscypliny w kościele, uważał, że zamiast o dyscyplinę należy się starać o odkrycie prawdziwej nauki i o pokój powszechny, opierający się na zgodzie, tolerancji i wolności sumienia ${ }^{134}$. Kwestie tolerancji i wolności sumienia dotyczyły już nie samego kościoła, lecz przede wszystkim - prerogatyw władzy świeckiej.

130 Por. Notae in Hugonis Grotii Votum pro pace, s. 59 („Neque enim inter corporis membra ulli sunt eiusmodi gradus. Itaque talis est Ecclesiae societas, qualis membrorum in uno corpore, in quo, solo capite, quod in Ecclesia Christus est, excepto, nulli sunt superiorum $\&$ inferiorum potestatum gradus; sed tantum facultatum, \& operationum”), 152-153 („Episcopi non sunt Presbyterorum principes (quo dignitatis titulo nunquam usa est prima illa \& sancta Ecclesia) sed presbyterorum praecipui”).

131 Por. ibidem, s. 154.

132 Por. ibidem, s. 54 („Qui si a norma semel \& ab initio tradita discedant audiendi non sunt: nec tum plebs subjecta iis esse debet, sed illi plebi, imo cuiq. rectiora monenti ex plebe, secundus ipsius Petris praeceptum"). Zapewne odwołanie do 1 P 5, 6 (Wulgata: „humiliamini igitur sub potenti manu Dei ut vos exaltet in tempore visitationis"), który Szlichtyng komentował w: Commentarius in priorem Epistolam Apostoli Petri, w: Bibliotheca Fratrum Polonorum, t. 3, cz. 2, s. 335 („Ideo humiliamini. Id est vosmetipsos quammaxime demittite, infra omnes ponite $\&$ minimos ducite, quemvis hominem vobis honore praeferte, proinde cuilibet vera monenti vosmet subjicite, nihil vobis veri honoris decedet, si quemvis honore praeveneritis, et rectiora monenti vosmet subjeceritis").

133 Por. Notae in Hugonis Grotii Votum pro pace, s. 90.

134 Por. ibidem, s. 101 („Quanto rectius facerent, si ingenii vim ac doctrinae copiam, ingentia Dei dona, ad patefaciendam clarissimae veritatis lucem converterent, \& interea tamen non permiscendo falsis vera, paci communi studerent, \& Christianos omnes ad mutuam tolerantiam, \& permittendam conscientiis libertatem cohortarentur"). 
Broniąc poglądów Socyna na temat władzy świeckiej, Szlichtyng zauważył, że nie różnią się one od przekonań ortodoksji protestanckiej. Socyn, a za nim i sam Szlichtyng pozostawili magistratowi wszystkie prerogatywy, które zostały mu powierzone przez Boga. Władza publiczna powstała, aby strzec publicznego pokoju oraz bezpieczeństwa niewinnych ${ }^{135}$. Zakres jej prerogatyw był więc podyktowany i ograniczony przez sprawowane funkcje. Według nakazów Ewangelii powinna ona działać adekwatnie do potrzeb i łagodnie: na przykład nie wymierzać kary śmierci za kradzież $\dot{1}^{136}$. Miecz powierzony magistratowi przez Boga powinien spoczywać „ukryty w pochwie miłości”"137.

Sformułowania te nie oznaczały jednak, że Szlichtyng bezwzględnie potępiał wojnę, karę śmierci i wszelkie formy pozbawiania życia, choć jego stosunek do tych instytucji określić trzeba jako złożony i ambiwalentny. Teolog - podobnie jak Hugo Grotius - przyznawał magistratowi prawo do prowadzenia wojen przeciw publicznemu wrogowi, lecz zakazywał wojen prywatnych ${ }^{138}$. Dopuszczał wojny obronne ${ }^{139}$, zarazem jednak trzeźwo zaznaczał, że wojna toczona w interesie wspólnoty, bez nadużyć, nienawiści i grabieży, jest czystą teorią, „a nie żyjemy w świecie platońskich idei” ${ }^{140}$.

Szlichtyng, podobnie jak Socyn, krytykował karę główną, jeżeli wywodziła się ona z koncepcji „animae pro anima adem[p]tio”, a więc odrzucanej przez braci polskich zasady odpłaty, czyli zemsty („vindicta”), która odwoływała się do starotestamentowej zasady „oko za oko” ${ }^{141}$. Jednak teolog nie potępiał zabijania bezwzględnie, ostrożnie ważąc słowa

135 Por. Quastiones dua, s. 334 („Reliquimus libenter Magistratui sua jura ac potestatem, quam ab ipso Deo accepit, et quidquid ad illum finem obtinendum, quem Magistratus habere sibi debet propositum, publicam nimirum pacem et securitatem, seu bonorum et innocentium defensionem necessarium est"); Notae in Hugonis Grotii Votum pro pace, s. 155; Apologia pro veritate accusata, s. 79-80.

136 Por. Quastiones dua, s. 393-394.

137 Por. ibidem, s. 426 („gladium istum, quo armatus a Deo est, in charitatis, ut sic dicam, vagina, si non prematur necessitate, reconditum gestare").

138 Por. ibidem, s. 375-376, 395.

139 Por. ibidem, s. 358-359 („Licet enim bellum, seu hostium propulsationem cum ipsorum nece conjunctam improbet, et Christi praeceptis contrariam esse dicat; non loquitur tamen de bello, seu hostium invadentium caede, quam Magistratus ipse, conductis eam in rem militibus conservandae Reipublicae causa peragit”).

140 Por. ibidem, s. 410-411 („Verum meminisse debebas, nos in Platonis republica nequaquam versari, nec de bellorum idei loqui").

141 Por. ibidem, s. 337. 
na temat przemocy, wojny oraz prawa jednostki do obrony. Odpierając zarzuty, iż Socyn odmówił magistratowi prawa do prowadzenia wojny i sprawowania sądów, Szlichtyng podkreślał, że polemika Socyna z Jakubem Paleologiem dotyczyła jedynie obowiązków chrześcijanina i prawa jednostki do samoobrony. Powyższe zastrzeżenia przenosiły debatę na pole indywidualnej etyki, co więcej - przeciwstawiały etykę zasadom życia publicznego ${ }^{142}$.

Teoretyczna akceptacja państwa, sądownictwa i wojny prowadziła do pytania o stosunek jednostki do tychże instytucji. Szlichtyng podkreślał, że choć Bóg pragnie, aby wierzący ćwiczyli się w łagodności i wyrozumiałości, to chrześcijanin ma prawo z czystym sumieniem odwoływać się do decyzji władzy świeckiej, zarówno przed, jak i po doznanej niesprawiedliwości. Nie wolno mu jednak domagać się od magistratu zemsty ani poszukiwać jej na własną rękę ${ }^{143}$. Zakazane jest także zabijanie, gdyż z punktu widzenia etyki chrześcijańskiej zabójstwo zawsze jest złem, dopuszczalnym jedynie w obronie własnej ${ }^{144}$.

Kwestii pozbawienia człowieka życia - poruszanej na przykładzie kar wymierzanych przez władzę świecką oraz instytucji wojny - poświęcił Szlichtyng dość dużo miejsca, rozprawiając się zarówno z biblijną (staroi nowotestamentowa) argumentacją, jak i z uzasadnieniem tego czynu przez prawo natury.

Analiza przekazów biblijnych skłoniła Szlichtynga do odrzucenia argumentów na rzecz kary śmierci i dopuszczalnego zabójstwa, czerpanych ze Starego Testamentu. Wedle arianina owe barbarzyńskie czasy nie mogą być przykładem dla chrześcijan ${ }^{145}$. Także często przywoływana nowotestamentowa scena sięgnięcia po miecz przez Piotra w obronie

142 Por. ibidem, s. 427 („Iam si quis hinc, quod de Magistratus concedimus, colligat, privatis similiter non omnino hoc praecepto caedium et fundendi sanguinis jus adimi, is cogitare debet, aliam esse rationem Magistratus, aliam privatorum. Ille enim tale a Deo accepit officium, quod sine gladii potestate consistere non potest”), 437 („Respondeo primo, nos non agere de Magistratu, sed de privatis").

143 Por. ibidem, s. 354-355.

144 Por. ibidem, s. 365 („Et tamet ipse Meisnerus agnoscit, homicidium extra necessariam vitae defensionem esse per se et natura sua malum, quemadmodum apparet ex iis conditionibus, quibus privatam defensionem cum caede alterius conjunctam statim ab initio circumscripsit").

145 Por. ibidem, s. 361, 377-379 (,alia nunc fluunt tempora, quam olim; et alios homines, alios mores desiderant”), 383, 386 („Licet enim postea Deus Magistratum in populo suo instituerit, et ei jus gladii in homicidas dederit, bestiam etiam, quae 
Chrystusa nie była dostatecznym uzasadnieniem. Wedle Szlichtynga, wystąpienie Piotra było ze wszech miar słuszne, ale należało je właściwie zinterpretować: Piotr wystąpił nie w obronie własnej, lecz w obronie najbliższych; sam magistrat zaś aresztując Chrystusa, postąpił niesłusznie i bezprawnie, stając się tym samym władzą tyrańską ${ }^{146}$.

Odwołanie do kategorii obrony najbliższych (rodziny, przyjaciół i ojczyzny) oraz sprzeciwu wobec tyrańskiej władzy, a także „necessaria vitae defensio" było jednoznacznym nawiązaniem do pism Cycerona i neostoickiej teorii prawa natury, ale prowokowało do pytań o granice owej obrony koniecznej ${ }^{147}$. Meisner bronił w tej sytuacji zasady „vim vi repellere licet”, uważając ją za wynikającą z prawa natury, a więc również za niesprzeczną (a być może nawet zgodną) z nakazami bożymi, prawo natury zostało bowiem stworzone przez Boga. Szlichtyng odrzucał jednak również taką argumentację, uważając, że Bóg może zmieniać własne prawa ${ }^{148}$, a od podszeptów natury ważniejsze są nakazy pobożności. Ostatecznie bowiem obrona własna możliwa jest bez zabijania, a chrześcijanin powinien wyżej cenić zbawienie niż własne życie.

Po uznaniu racji istnienia świeckiego magistratu i prawa chrześcijanina do korzystania z niego, należało jeszcze rozstrzygnąć kwestię sprawowania urzędów przez chrześcijanina, płacenia podatków oraz możliwości oporu wobec władzy. W 1636 r. Szlichtyng zamiast udzielić odpowiedzi sformułował pytanie retoryczne: nawet jeżeli Bóg przyznał magistratowi prawo do zabijania, to jednak czy przystoi chrześcijaninowi zwracać się do

hominem occiderit, necari jusserit, tamen hoc ad ista tempora, quibus antiquissimam hanc legem promulgavit, trahendum non est"), 412-413.

146 Por. ibidem, s. 387-388 („Profecto Magistratus in hoc negotio non Magistratus officium gessit, sed iniquissimi tyranii personam sustinuit [...] Adde , quod Christus, utpote Dei ipsius unicus Filius, omniumq. Dominus ac haeres futurus, Magistratui, qui Dei minister est, vere subjectus non fuerit, praesertim ita, ut Christi capiendi et invadendi [n]ullum jus habuerit").

147 Por. R. v. Friedeburg, In defense of patria: Resisting magistrates and the duties of patriots in the Empire from the 1530s to the 1640s, „Sixteenth Century Journal”, 2001, 32, s. 357-382; A. Schmidt, Vaterlandsliebe und Religionskonflikt. Politische Diskurse im Alten Reich (1555-1648), Brill, Leiden 2007, s. 27.

148 Por. Quastiones dua, s. 368 („Nec refert, quod lex naturae suam ab ipso Deo habeat originem. Deo enim leges a se latas, novis et melioribus legibus abrogare liberum est”), 458 („Nec tantum spectandum est ad quod nos instiget natura, sed etiam quid permittet Christiana pietas et patientia"). 
magistratu i sprawować urzędy? ${ }^{149}$ Sugerował tym samym, że chrześcijanin w obliczu konfliktu nakazów wiary i praw powinien wycofać się z życia politycznego. Prawdziwy chrześcijanin, wedle Szlichtynga, woli umrzeć w cierpieniach niż na wojnie - jako męczennik, nie jako żołnierz ${ }^{150}$.

Mimo to chrześcijanin powinien płacić podatki, nawet gdy służą one prowadzeniu wojny: także Chrystus wiedział, co robią z pieniędzmi cesarze $^{151}$. W tym właśnie widział Szlichtyng różnicę między manichejczykami, odrzucającymi władzę świecką jako zło, a socynianami - akceptującymi ją, lecz, „quantum possunt”, wzdragającymi się przed wojnami i rozlewem $\mathrm{krwi}^{152}$. Na uwagę zasługuje nieprzypadkowa modalność owych zakazów: Szlichtyng nie formułuje bezwzględnych imperatywów, lecz posługuje się zawsze sformułowaniami „velle”, „nolle”, „malle”, „quamtum possere” lub „quam maxime”.

Swobody chrześcijanina w jego ojczyźnie były gwarantowane przez wolności i prawa. Właśnie ujęcie kwestii wolności przez myślicieli ariańskich zostało uznane przez badaczy za szczególnie nowatorskie ${ }^{153}$. W wywodach

149 Por. Quastiones dua, s. 384 („Verum hoc etiam largiamur, Deum hac lege Magistratum instituere, et illi jus homicidas necandi tradere: nam idcirco etiam Christiano homini vere pio ac sancto licebit operam suam ea in re Magistratui commodare, et ejus ministrum agere?").

150 Por. ibidem, s. 405 („At Christiani, si moriendum omnino est, in persecutione mori malunt, quam in bello, tanquam martyres potius, quam tanquam milites, animamque sine alterius vulnere ponere longe pulchrius esse ducunt”), 433, 456 („At vero nos Christiani, quoties a regibus ac magistratibus premimur, non quod non possimus, sed quod nolimus resistere, injurias ferre debemus").

151 Por. ibidem, s. 421-422.

152 Por. ibidem, s. 419 („Aliter enim bella improbant, qui dicunt, Magistratus et politias a Deo malo esse constitutas, Mosen reprehendendum quo bella gesserit, quod Manichaei fecisse dicuntur: aliter illa improbant, qui Magistratus ab ipso Deo constitutos, et gladio etiam armatos esse fatentur, qui Mosen jussu divino bella gessisse asserunt; caeterum Christianos homines, quibus hostes diligere sit imperatum, a bellis et caedibus quantum possunt arcent, nec cuiquam privato, qui vere pius esse velit, ultro in bellum proficisci, et hostes occidere fas esse putant").

153 Por. rozważania głównie na podstawie dzieł Samuela Przypkowskiego: Z. Ogonowski, Samuel Przypkowski i jego traktat De pace et concordia Ecclesiae, „Studia Filozoficzne”, 1981, 2, s. 89-102; Id., La liberté de citoyen et la liberté religieuse dans la philosophie politique en Pologne au XVIIe siècle, OiRwP, 1995, 39, s. 155-162; Id., Der Sozinianismus und das Problem der Toleranz, w: Faustus Socinus, s. 129-145; Id., Filozofia polityczna w Polsce XVII wieku i tradycje demokracji europejskiej, PAN IFiS, Warszawa 1999, s. 111-114, 128-134. 
dotyczących prawa do wolności religijnej Szlichtyng często powoływał się na przywileje stanowe szlachty oraz postanowienia Konfederacji Warszawskiej ${ }^{154}$. Przez owe prawa rozumiał zapewne nie tylko akty prawne, lecz i niepisane zasady ugruntowane w tradycji tworzącej kulturę polityczną szlachty. Dopiero import egzotycznych zwyczajów (Szlichtyng często wskazywał na hiszpańską inkwizycję) doprowadził do złamania praw i naruszenia tych tradycji ${ }^{155}$. W $1654 \mathrm{r}$. Szlichtyng otwarcie oskarżał Rzeczpospolitą o nietolerancję religijną ${ }^{156}$. Nie miał także wątpliwości, że los prześladowanych braci polskich podzielą inne wyznania protestanckie ${ }^{157}$.

Odwołanie do przywilejów i praw Rzeczypospolitej stanowiło fundament koncepcji wolności, którą można tu nazwać stanową. Wolność w tym ujęciu nie była podmiotowym prawem jednostki, przysługującym jej niezależnie od urodzenia i pozycji społecznej, lecz wiązała się z przynależnością do konkretnego stanu społecznego, choć niekoniecznie szlachty. W tę koncepcję wpisuje się także odwołanie do Konfederacji Warszawskiej.

Niezależnie od tej argumentacji Szlichtyng rozwijał także inną, wedle której wolność wyznania była nienaruszalnym aksjomatem. Już w polemikach z Meisnerem zaznaczał, że władza powinna powstrzymać się od prześladowania herezji, wyznanie było bowiem sprawą wiary, więc przymus fizyczny był po prostu nieskuteczny ${ }^{158}$. Argumentację tę Szlichtyng

154 Por. Epistola Apologetica, s. 2, 18.

155 Por. Confessionis Christianae ad rogum damnatae, s. 17; Apologia pro veritate accusata, s. 4.

156 Por. Apologia pro veritate accusata, s. 41 („Poloniam deinde, infausto omnine commemorant, patriam nostram; quae dum non tantum nobis, sed etiam Euangelicis, $\&$ aliis, contra jurisjurandi $\&$ faederum fidem, templa adimit, exercendae religionis libertatem labefactat, $\&$ variis pressuris ob diversum in sacris sensum, infestam sese praebet; vindicem Dei manum in se provocavit, \& iis sese cladibus $\&$ calamitatibus involvit, quarum necdum finem videmus ullum; quae quamdiu fartam tectam cuivis servavit conscientiae $\&$ religionis libertatem, altissima pace $\&$ omnium bonorum faelicitate cumulata floruit; sed ubi vinculum illud, aequabili lege omnes de rebus divinis dissentientes continens, solvi caepit, omnia «in pejus ruere $\&$ retro sublapsa referri»"). 157 Por. ibidem, s. 3-4 („Audite caeteri dissidentes, quid \& vobis sperandum sit. Ubi nos tanquam non Christianos exegerint, eundem \& vobis cothurnum induent; qui ita comparatus est, ut $\&$ vestro pedi aeque aptari possit. Sed si juribus, non viribus disceptamus; non vides, cautionem illa pacis, cuique jus facere, ut ex suo sensu $\&$ conscientia Christianae fidei rationem limitesque definiat?”).

158 Por. Quastiones dua, s. 469 („Quid magis liberum esse debet, quam aliquid dicenti credere vel non credere? cum fidei natura omnem coactionem repudiet. Quis enim, ut aliquid revera credat, vi cogi potest?"); Apologia pro veritate accusata, s. 5-6. 
rozwinął w apologiach publikowanych w latach pięćdziesiątych XVII w. Kreślił tam obraz wzajemnej wrogości między konfesjami, pytając, czy również arianie mieliby prawo wykluczyć katolików, gdyby przypadkiem okazali się silniejszą konfesją ${ }^{159}$. Było to pytanie podważające zasadę pokoju augsburskiego, znaną jako „cuius regio eius religio”, która zyskała niezwykłą popularność w XVII w. jako sposób na zapewnienie pokoju między skłóconymi wyznaniami. W jej miejsce Szlichtyng proponował rozdział kościołów i państwa, państwo skupiało w sobie bowiem „ludzi różnego pochodzenia i różnych religii, nawet bałwochwalców, pogan, heretyków i apostatów" ${ }^{160}$. Władza świecka miała status obrońcy kościoła, lecz tylko przeciw tym, którzy atakują kościół mieczem, a nie tym, którzy posługują się słowem i rozumem ${ }^{161}$. W obliczu różnicy zdań magistrat powinien powstrzymać się przed działaniem: „urząd słusznie postępuje wówczas, gdy w tego rodzaju sporze powstrzymuje się od działania, by nie zadawać gwałtu czyjemuś sumieniu" ${ }^{162}$. Dlatego nawet gdy w rozważaniach Szlichtynga pojawiła się figura Konstantyna, teolog wyjaśniał: „[...] ia[m] przykład Constantina wielkiego przytoczył, nie na to, żeby Jego Mość controversie między nami rozstrzygał, przykim prawda abo nie: ale żeby Jego Mość zgodę y pokoy między roznie rozumieiącymi, każdego przy swym zdaniu zostawiwszy, promowować chciał"163.

159 Por. Confessionis Christianae ad rogum damnatae, s. 4 („Nemo enim de alterius Religione male sentit, quin $\&$ alter de illius itidem male sentiat. An ergo si nobis hae vires essent, quae nunc vobis sunt, fas foret eundem in vos praetextum sumere, (quo nihil facilius,) \& sic a communi pace ac libertate vos excludere?”).

160 Por. Apologia pro veritate accusata, s. 108 („Discinta enim inter se sunt, Ecclesia $\&$ Respublica, nec sine omnium rerum perturbatione confundi possunt [...] Respublica recipit \& fovet cujuscunque generis \& Religionis homines, etiam idolatras, etiam paganos, etiam haereticos, etiam a Christi nomine apostatas, $\&$ illae demum Respublicae vel maxime, populorum multitudinae $\&$ civium concordia florent”). Tłumaczenie tego fragmentu w: Myśl ariańska, s. 97.

161 Por. Apologia pro veritate accusata, s. 38 („Verum est, Civiles Potestates Ecclesiae Educatores \& Tutores esse: sed adversus illos, qui Ecclesiam armis, \& externa vi invadunt; non qui solas Scripturas \& rationes offerunt, parati aut Ecclesiam melius erudire si erret; aut ab Ecclesia, si ipsi errent, erudiri”); ibidem, s. 116 („Vos, quibus Civilis in alios potestas commissa est, illi ministri, \& famuli estis").

162 Por. ibidem, s. 95 („Magistratus igitur recte facit, dum in tali discrimine, manum cohibet, ne conscientiae cujusquam vim inferat"; tłumaczenie za: Myśl ariańska, s. 93). Por. Apologia pro veritate accusata, s. 116-117, 119.

163 Odpowiedź, s. 14. 
Aksjomat wolności sumienia był w rozważaniach arianina ugruntowany nie tylko w autonomii instytucji kościoła, lecz także w relatywizmie oraz w autonomii jednostki. Podobnie jak poglądy Szlichtynga wydawały się bluźniercze Cichowskiemu, tak i poglądy Cichowskiego nie były słuszne w oczach Szlichtynga ${ }^{164}$. Dlatego herezje nigdy nie były i nie powinny być ścigane prawem, lecz winny stać się przedmiotem racjonalnej dysputy ${ }^{165}$. W prawie do swobodnego decydowania o własnym wyznaniu znajdowała bowiem wyraz wolność sumienia przysługująca każdemu chrześcijaninowi ${ }^{166}$ : „Czymże innym jest bowiem wolność sumienia, które jedynie Bogu jest podporządkowane, niż myśleć w sprawach religii, co chcesz, a co myślisz - swobodnie głosić i czynić, jeżeli nikomu nie wyrządzasz krzywdy?" 167.

Innymi słowy, owa indywidualna wolność sumienia pociągała za sobą prawo jednostki do swobody myśli i wypowiedzi. Jej gwarancją był zaś rozdział państwa i kościoła.

„Żem to wziął z onego wielkiego Erasma [...], wy starzy y biegli Theologowie mogliście to wi ed zi eć”

Jak wspomniano, większość z prezentowanych poglądów nie była oryginalnym wytworem Szlichtynga, lecz stanowiła rozwinięcie idei zawartych w pismach Fausta Socyna. Nie powinno to dziwić, ponieważ wiele

164 Por. Confessionis Christianae ad rogum damnatae, s. 14-15 („Quod libros meos blasphemos vocet, non miror; sic enim sentit, sic arbitratur; sed quod me in liberrima Respublica blasphemiae nomine damnare fuerit ausus, propter meum ab ipso in Christiana fide dissensum, hoc demiror querorque. Nam quae ipsi blasphemiae videntur, mihi sunt sancta dogmata. Nec mirum, cum et mihi non omnia videantur vera \& sancta, quae ipsi videntur esse sanctissima”); Apologia pro veritate accusata, s. 95 („Nemo nostrum sciens, prudens, blasphemat. Nam quae isti blasphema putant, nobis sancta sunt, \& cum ab istis blasphema appellantur, blasphemare eos credimus").

165 Por. Apologia pro veritate accusata, s. 111.

166 Confessionis Christianae ad rogum damnatae, s. 5 („quo jure mea haec Confessio, Christiana dici non posse, in civili foro, pronuntiata est? si Respublica meum mihi sensum \& liberum in Christiana religione conscientiam reliquit nec ullum Civem, qui Christianum, se se damnaturam esse tot sanctissimis vinculis fidem suam obstrinxit”). 167 Apologia pro veritate accusata, s. 99 („quid enim aliud est conscientiae, uni vero Deo adstrictae, libertas; quam in Religione sentire quae velis, \& quae sentias, libere pronuntiare, \&, quod citra cujusque injuriam sit, facere!”). Por. tłumaczenie w: Myśl ariańska, s. 95. 
z polemik miało apologetyczny charakter: służyło obronie Kościoła braci polskich, na którego czele stanął Szlichtyng, oraz koncepcji Socyna. Wybór adresatów przedmów i dedykacji (Bogusław Leszczyński, Jan Jerzy Szlichtyng, szlachta ewangelicka) dowodzi, że odbiorcami owych pism byli również wyznawcy innych konfesji. Dlatego ariański teolog, przywołując autorytety i dokumentując swoje wywody, najczęściej odwoływał się nie do myślicieli ariańskich, lecz do Ojców Kościoła oraz współczesnych teologów innych wyznań.

Spośród Ojców Kościoła Szlichtyng chętnie powoływał się na autorytet Tertuliana ${ }^{168}$, a ponadto Ireneusza z Lyonu, Ignacego Antiocheńskiego, Justyna i Orygenesa ${ }^{169}$. Spośród autorów współczesnych wyróżniał Erazma z Rotterdamu i Sebastiana Castelliona ${ }^{170}$. Zwłaszcza Erazm cieszył się szacunkiem Szlichtynga: „Człowiek to był wielki, i mądry, i mało sobie miał równych abo i podobnych" ${ }^{171}$. Owo przywołanie Erazma pełniło oczywistą funkcję identyfikującą: Szlichtyng wpisywał się w krąg tradycji humanistycznej. Zarazem miało także wydźwięk antyklerykalny: teolog stylizował się na osobę świecką ostrzegającą odbiorców przed zagrożeniem ze strony duchownych.

Nie oznacza to oczywiście, że Szlichtyng był laikiem w aktualnych debatach teologicznych. We wszystkich polemikach najchętniej cytował pisma Jana Kalwina i Teodora Bezy, które zdawał się znać lepiej nawet od adwersarzy należących do wyznania reformowanego ${ }^{172}$. Bardzo rzadko natomiast przywołuje autorytet Lutra i jego dzieła, choć zdarzało mu się wytknąć Meisnerowi, że jego tezy odbiegają od Lutrowych ${ }^{173}$. W owym

168 Por. Na Antapologia [...] odpowiedź, s. 269-270; De ss. Trinitate, Praefatio (osobna paginacja).

169 Por. Confessionis Christianae ad rogum damnatae, s. 6, 92-93.

170 Por. Na Antapologia [...] odpowiedź, s. 95.

171 Ibidem, s. 159, 173. Por. P. Bietenholz, Fausto Sozzini and the New Testament Scholarship of Erasmus, w: Faustus Socinus, s. 11-28.

172 Por. Odpowiedź, s. 104 („Wejrzeć że było przynamniej w Bezę, którego znać nie pilno czytacie"); Na Antapologia [...] odpowiedź, s. 264-265; Questiones dua, s. 202 (zestawienie poglądów Augustyna i Bezy). Por. De ss. Trinitate, s. 450 („Recte monet Beza), 482, 625 („ut recte explicat Beza”); Notae in Georgii Vechneri Concionem, s. 7, $37,45,83$.

173 Por. De ss. Trinitate, s. 895; por. ibidem, s. 808 (jedyny niemieckojęzyczny ustęp w dziełach Szlichtynga to cytat z Lutra: „Solch groß gnad unndt barmehrzigkeit // Sucht eine herz in grosser arbeit // Ist dir wol / so bleib darvon // Das du nicht kriegest bösen lohn"; był to fragment Abendmahlslied z 1524 r.). 
stosunku do Ojców reformacji należy zwrócić uwagę na pewną ambiwalencję. Z jednej strony bowiem Szlichtyng zauważał, iż głos Kalwina nie wszędzie wśród ewangelików reformowanych jest szanowany ${ }^{174}$. Z drugiej strony krytykował Clementinusa, że ten zbyt często polega na autorytetach, nie znając w istocie Pisma Świętego. Arianin zarzucał teologom protestanckiej ortodoksji: „więcey w Calwinie, w Bezie, i w Ojcach, jako je zowią, kościelnych się ćwiczycie, i w nich bieglejszemi jesteście niż w samym piśmie ś." ${ }^{175}$. Innymi słowy - ortodoksja protestancka stworzyła nową scholastykę, która - podobnie jak scholastyka katolicka - stała się fundamentem postaw nietolerancyjnych i prześladowania heretyków, czego przykładem wydarzenia w Niderlandach oraz proces Miguela Serveta ${ }^{176}$. Również ortodoksja luterańska stworzyła męczenników, więżąc i skazując na wygnanie Joachima Stegmanna, Jana Vogla (Joannesa Vogeliusa), Joachima Peschela (Peuscheliusa) ${ }^{177}$. Także w Rzeczypospolitej antytrynitarze nie byliby tolerowani, gdyby zależało to od duchownych ewangelickich ${ }^{178}$.

Co ciekawe, Szlichtyngowi zdarzało się także powołać na Stanisława Hozjusza, Roberta Bellarmino, a nawet Piotra Skargę ${ }^{179}$. Niewątpliwie najciekawsza rola przypadła Hozjuszowi, który został przywołany jako obrońca prawa braci polskich do rezydowania w Rzeczypospolitej ${ }^{180}$.

174 Por. Na Antapologia [...] odpowiedź, s. 101.

175 Odpowiedź, s. 15-16.

176 Por. Na Antapologia [...] odpowiedź, s. 27-28 („Niech się przypatrzą temu, co ich towarzysze w Niderlandzie już to od lat dziesiąt broją. Wszak tam Calvin i Beza każą Heretyki, to jest tych, którzy się im zdadzą Heretykami, palić i mordować. A nie tylko księgi o tym pisali, ale też i próbę tego w Serwecie pokazali”); Apologia pro veritate accusata, s. 40-41.

177 Por. Quastiones due, s. 462.

178 Por. Na Antapologia [...] odpowiedź, s. 193 („gdzież jest to Królestwo, to Xięstwo, to miasto, ta Rzeczpospolita, w której byście całą zwierzchność i władzą mając, naszych cierpieć chcieli? Anglia, Genewa, Niderland niechaj świadczą, a że nas w Polscze, tak srodze nas nienawidząc, mieczem i ogniem nie trapicie, częścią wrodzona niektórych cnota, i baczenie, że się nikogo dla sumnienia uciskać nie godzi, i miłość pokoju pospolitego; częścią commune periculum, i spólne niebezpieczeństwo sprawuje”).

179 Por. Confessionis Christianae ad rogum damnatae, s. 6-7, 121-122.

180 Przypomniał to Szlichtyng w: Epistola Apologetica, s. 3 („Hosium Cardinalem, cum in patria nostra Legatum ageret, \& consilio interesset de aliis haereticorum tolerandis, aliis autem regno pellandis (Majores nostri denotabantur) improbasse id consilium proditum est; quod diceret, multum interesse Ecclesiae, si haereticorum inter sese dissensiones relinquerentur"). 
Szlichtyng cytował słynne słowa Hozjusza „bellum enim haereticorum pax est Ecclesiae", które włożył w usta kardynała jego biograf Stanisław Reszka $^{181}$.

"Sam nie pamiętasz, co w Antapologii pisałes”" Bez postawienia pytania o ewolucję tych zapatrywań rekonstrukcja poglądów teologa pozostanie niepełna. Trudno udzielić na nie jednoznacznej odpowiedzi ze względu na charakter twórczości Szlichtynga i stan jej zachowania. Poglądy zawarte w utworach polemicznych i przedstawione powyżej można jednakże zestawić z treściami Confessio fidei. Stosunkowo niewielki rozmiar Confessio fidei, liczącej 26 stron (dwie edycje z $1651 \mathrm{r}$. miały 104 i 126 stron), zwłaszcza w porównaniu z liczącymi tysiące stron polemikami, nie powinien być argumentem przeciw takiemu zestawieniu. Wyznanie było bowiem najważniejszym dokumentem doktrynalnym braci polskich od czasu publikacji Katechizmu Rakowskiego ${ }^{182}$. Publikacja wyznania w 1642 r. była swoistym zwieńczeniem i ukoronowaniem rozwoju refleksji teologicznej Szlichtynga, ale także - jak starano się wykazać poniżej - radykalnym zwrotem. Cichowski dostrzegłszy te zmiany, zarzucał Szlichtyngowi, iż zapomniał, o czym i jak pisał wcześniej ${ }^{183}$. Szlichtyng usprawiedliwiał się $\mathrm{w}$ apologii wyznania, że zmiany polegały jedynie

181 Por. D. Stanislai Hosii [...] Vita auctore Stanislao Rescio, w: Stanislai Hosii S. R. E. Cardinalis Episcopi Varmiensis [...] Epistolae, t. 1, ed. F. Hipler, V. Zakrzewski, Cracoviae 1879, s. LXIV. Por. S. Bodniak, Sprawa wygnania arian w r. 1566, RwP, 1928, 5, s. 52-59.

182 Por. Confessio fidei. Por. także wydanie z 1651 r. noszące na stronie tytułowej adnotację „secunda editio correctior”. Ponieważ Radoń (por. Id., op. cit., s. 27) sugeruje, że między dwoma wydaniami istnieją znaczące różnice, w poniższej analizie wykorzystano obie edycje. Angielskie tłumaczenie i komentarz w: The Polish Brethren. Documentation of the History and Thought of Unitarianism in the Polish-Lithuanian Commonwealth and in the Diaspora 1601-1685, ed. G. H. Williams, vol. 2, Scholars Press, Ann Arbor 1980, s. 389-418; G. H. Williams, The Place of The Confessio Fidei of Jonas Schlichting in the Life and Thought of the Minor Church, w: Socinianism and its Role in the Culture, s. 103-114. Poniższe tezy przedstawiono skrótowo także w: M. Ptaszyński, Jonasz Szlichtyng (1592-1661), s. 177-179.

183 Por. polemikę M. Cichowski, Manes Slichtingiani seu trutina vindiciarum manium Confessionis Socinianae: Varsaviae exustae: editarum a D. Iona Slichting. Producta in publicum a Patre Nicolao Cichovio, [b.m.], Typis Viduæ \& Heredum Andreæ Petricovii [1659], s. 98 („omissis multis, quae Socino, Smalcioque obiecta purgare non potuit: adeoque suo ipso silentio damnavit [...] Tu ipse Domine, non meministi, quae in Antapologia scripseris?”). Przeciwna konkluzja w: S. Radoń, op. cit., s. 27. 
na przemilczeniu oraz że był to celowy zabieg wykluczenia z wykładu prawd wiary kwestii przerastających ludzki umys ${ }^{184}$. Analiza wyznania przekonuje, iż nie do końca należy w te usprawiedliwienia wierzyć.

Confessio fidei została przygotowana przez Szlichtynga w formie komentarza do apostolskiego wyznania wiary. Szlichtyng poprzedził dzieło jedynie krótkim wstępem, w którym aprobował symbol nicejski (Niceanum) oraz wyraził dystans w stosunku do trzeciej części Credo, poświęconej Duchowi Świętemu ${ }^{185}$. W komentarzu do artykułu o Duchu Świętym (art. 19) określił go mianem „Instruktora, Nauczyciela i Świadka” (w wyd. z 1642: „Doctorem et Magistrum, et Testem”, w wyd. z 1651: „caelestem Authorem, et Magistrum, et Ducem, et Testem”) zesłanego przez Chrystusa po wniebowstąpieniu ${ }^{186}$. W tych ostrożnych i dwuznacznych sformułowaniach można jedynie domyślać się próby odmówienia Duchowi przymiotu osoby ${ }^{187}$. Szlichtyng dyplomatycznie przemilczał także kwestię Trójcy.

Podobnie lakonicznie i dwuznacznie ują arianin kwestie chrystologiczne. Szlichtyng poruszył, co prawda, znane wątki, wykazując, że Chrystus jako spłodzony Syn Boży (art. 5) ma wśród istot boskich wyjątkowy status ${ }^{188}$. Jednocześnie wyraźnie podkreślił preegzystencję Chrystusa, który istniał przed wcieleniem, a także przed stworzeniem świata ${ }^{189}$. Również

184 Por. Confessionis Christianae ad rogum damnatae, s. 63 („Nam de eo, an Deus ille unus, \& Patris Personam, quae non sola unus ille Deus sit, \& Filii Personam alteram, \& Spiritum S. tertiam, sine ulla unius essentiae inter ipsas distinctione, includat, disputare hic in simplice Confessione nolumus, cum istius rei cogitatio, omnem humanum intellectum superet").

185 Por. Confessio fidei [1642], k. A3r-v; Confessio fidei [1651] s. 4 („Porro dissimulandum non duximus tertiam Symboli istius partem, quae de fide in Spiritum S[anctum] et in ea quae sequuntur agit, quamvis verissima fidei Christianae dogmata contineat, non ejus tamen antiquitatis a quibusdam censeri, ut eam cum prioribus duabus partibus, quibus fides in Deum et filium ejus Jesum Christum describitur, ab ipso statim initio conjunctam fuisse existiment”). Por. J. Jørgensen, Stanistaw Lubieniecki, s. 150.

186 Por. Confessio fidei [1642], s. 22; Confessio fidei [1651], s. 81.

187 Por. Confessio fidei [1642], s. 22 ([Spiritus S. est] „Dei promissio, Dei donum quo perfundimur et imbuimur, Dei unctio, Dei virtus, qua remplemur"); Confessio fidei [1651], s. 6, 84 („Idem Spiritus S. est digitus Dei, promissio Dei, donum Dei, quod Deus largitur petentibus se, distribuitque ad arbitrium suum, aliis plus, aliis minus de illo conferens").

188 Por. Confessio fidei [1642], s. 6, 8, 10; Confessio fidei [1651], s. 24, 33, 41.

189 Por. Confessio fidei [1642], s. 21 („Credimus igitur Iesum Christum ante mundi jacta fundamenta a Deo praecognitum, et dilectum fuisse, eundemque multo magis 
w wykładni śmierci i ofiary Chrystusa (art. 11) można dostrzec radykalną zmianę $^{190}$. Według George’a H. Williamsa, Szlichtyng nawiązał zarówno do teorii Anzelma i Abelarda, jak i Socyna oraz Kalwina ${ }^{191}$. Śmierć Chrystusa miała być zarazem satysfakcją gniewu bożego, przykładem dla żyjących, jak i ofiarą, dzięki której chrześcijanom zostaje przypisana sprawiedliwość. Przynajmniej dwie z tych koncepcji (satysfakcji oraz ofiary) Szlichtyng dotąd zdecydowanie odrzucał.

Również w innych sprawach, o które dotąd zażarcie walczył w dysputach, teolog zdecydował się albo nie zabierać głosu, albo wyrazić się dwuznacznie. Na przykład sformułowanie doktryny predestynacji, choć nie wyklucza udziału ludzkiej woli w dziele zbawienia, było bardzo ogólnikowe. Zagadnienia grzechu pierworodnego Szlichtyng w ogóle nie poruszył.

Tę teologiczną otwartość konfesji potwierdza ujęcie kwestii eklezjologicznych i sakramentologicznych. „Święty Kościół Katolicki” (Sancta Ecclesia Catholica) Szlichtyng zdefiniował możliwie szeroko jako zgromadzenie uznające Credo ${ }^{192}$. Konstytutywne dla niego, oprócz głoszenia słowa i pokuty, było rozdzielanie sakramentów chrztu i eucharystii. Ustęp poświęcony pierwszemu z nich jedynie sugeruje, że odnosi się do chrztu dorosłych, ale nie stwierdza tego jednoznacznie ${ }^{193}$. Eucharystia miała być rozdawana pod dwiema postaciami, zarazem jednak wyłącznie sformułowanie o „pamiątce” śmierci Chrystusa („Memoriae mortis Christi”) przywodzi na myśl symboliczny charakter uczty eucharystycznej $\left(\right.$ art. 21) ${ }^{194}$.

ante Abrahamum ita fuisse, ut Abrahamus diem seu tempus illius venturi spiritu prophectico videre potuerit”); Confessio fidei [1651], s. 75 („Credimus igitur, Jesum Christum, adhuc 'ante constitutionem mundi, et ante tempora secularia, a Deo fuisse praecognitum, et dilectum, ut hac ratione, et hoc sensu, adhuc ante constitutum mundum, et tempora secularia, proinde et ante Abrahamum, at ante omnes alios Prophetas fuisse, merito dicatur'”).

190 Por. Confessio fidei [1642], s. 12-13 („[Christus] pro nobis peccatoribus subiit, [...] fructus salutares qui ex his divinissimis muneribus Christi in nos promanant [...] omnia in coelis ac in terris reconciliavit, et ad pacem adduxit [...] per illam munus hoc sanctum expiatorium inchoavit. Nam sacratissimum suum sanguinem effudit, tanquam victima piaculoris, pro peccatis nostris"); Confessio fidei [1651], s. 49-52.

191 Por. G. H. Williams, The Place of The Confessio Fidei, s. 108.

192 Por. Confessio fidei [1642], s. 23; Confessio fidei [1651], s. 92-93.

193 Por. Confessio fidei [1642], s. 24; Confessio fidei [1651], s. 96.

194 Por. Confessio fidei [1642], s. 25; Confessio fidei [1651], s. 96. 
Confessio fidei jest utworem niezwykle koncyliacyjnym, bardzo bliskim doktrynie Kalwina i zdradzającym dobrą znajomość teologii reformowanej. Zbliżenie do reformowanej ortodoksji jest widoczne przede wszystkim w przemilczeniach w kwestiach dotyczących usprawiedliwienia: zaakceptowaniu odrzucanej wcześniej koncepcji „iustitia imputativa” i wykładu nauki o satysfakcji. Zarazem Szlichtyng starał się przemilczeć kontrowersyjne tematy predestynacji oraz formy chrztu. Pominął także dyskusyjne aspekty chrystologii, soteriologii i sakramentologii oraz antropologii lub ujął je ogólnikowo, chcąc zapewne zachować wierność myśli Socyna i Krella. Była to radykalna zmiana w stosunku do poglądów prezentowanych we wcześniejszym okresie.

Jednakże, jak zaznaczono powyżej, publikacja wyznania wiary nie zamknęła ewolucji poglądów Szlichtynga. W ostatnim okresie twórczości, po wyroku skazującym (1647), teolog częściowo wrócił na poprzednie pozycje i zrezygnował z języka ugody, choć dbał o zachowanie płaszczyzn porozumienia. Do przytoczonych już wyżej przykładów można dodać zmiany wprowadzone do nowej edycji Katechizmu Rakowskiego, gdzie Szlichtyng w istotny sposób zmodyfikował kluczowe kwestie chrystologiczne. Wbrew pierwotnej wersji Szlichtyng powtórzył przekonanie o boskości Chrystusa, który był, według niego, zarówno człowiekiem, potomkiem Dawida, jak i Bogiem. Rozwinął także koncepcję munus triplex Christi, obecną w pierwotnej wersji Katechizmu Rakowskiego: wbrew pierwodrukowi dodał jednak, że Chrystus był kapłanem (Sacerdos) również na ziemi, przed wniebowstąpieniem. W końcu także wykład znaczenia ofiary Chrystusa uległ modyfikacji i rozszerzeniu: Szlichtyng przejął wprawdzie explicite potępienie Anzelmowej koncepcji satysfakcji, zarazem jednak w wywodach dotyczących odkupienia odwoływał się do niej implicite.

Mimo że Szlichtyng zrezygnował w redakcji Catechesis z wielu koncyliacyjnych sformułowań Confessio fidei, to kontynuował próby teologicznego zbliżenia do wyznania reformowanego. Tendencja ta jest widoczna nie tylko w złagodzeniu doktryny chrystologicznej, ale także w oględniejszym sformułowaniu potępienia chrztu dzieci. Jest on, według Szlichtynga, błędem, który powinien być tolerowany ${ }^{195}$.

195 Por. Catechesis, s. 222 („quem tamen errorem [...] Christiana charitas tolerare suadet"). 
Wydaje się, że również w obszarze poglądów politycznych Szlichtynga można zaobserwować pewną ewolucję. Już we wczesnych polemikach Szlichtyng podkreślał, że obowiązki chrześcijanina nie stoją w sprzeczności ze służbą państwu, ale w późnych debatach często powracał temat patriotyzmu jako cnoty chrześcijanina ${ }^{196}$. W polemikach z Wolzogenem, gdzie bronił instytucji własności i państwa, obrona ojczyzny została przez niego wręcz uznana za obowiązek chrześcijanina ${ }^{197}$. W apologii wyznania wiary przyznawał: „My jesteśmy nie ludem obcym, ale krwią Rzeczypospolitej; zrodzeni jesteśmy z tych samych przodków" ${ }^{198}$. Nawet w Apologii kierowanej do Stanów Holandii i Fryzji Zachodniej, skarżąc się na ograniczenia swobód protestantów, odbieranie kościołów i ucisk, nie zawahał się nazwać Rzeczypospolitej „patria nostra”"

"Jedno z najlepszych piór [socynianów]"

Jonasz Szlichtyng należał do najwybitniejszych i najsilniej recypowanych teologów braci polskich. Jego dzieła, pisane przeważnie po łacinie, tłumaczono już w XVII w. na wiele języków europejskich ${ }^{200}$. Confessio fidei przełożono na polski (1646), francuski (1646), niderlandzki (1652) i niemiecki (1653). Dzięki edycji w zbiorze Bibliotheca Fratrum Polonorum jego pisma egzegetyczne zyskały szeroki odbiór w Niderlandach i w Anglii. Korzystali z nich między innymi Pierre Bayle ${ }^{201}$ oraz John

196 Por. Confessionis Christianae ad rogum damnatae, s. 16 („Majoribus Nobilitatis praerogativa debetur, non quatenus Romanae Ecclesiae fuerunt addicti, sed quatenus viri fuerunt strenui, resque egregias pro patria gesserunt").

197 Por. S. Kot, op. cit., s. 116-124, 137, 153; P. Brock, op. cit., s. 197-198.

198 Por. Confessionis Christianae ad rogum damnatae, s. 23 („Nos non externea gens; sed sanguis Reipublicae, iisdem orti Majoribus sumus”). Polskie tłumaczenie za: Filozofia i myśl, s. 672.

199 Apologia pro veritate accusata, s. 40-41.

200 Por. zbiór pism Szlichtynga: Aentekeningh en verklaringh.

201 Por. P. Bayle, Dictionnaire historique et critique, t. 13, Slatkine Reprints, Genève 1969, s. 359-360 (Schlichting jako „une de leurs [les sociniens - M.P.] meilleures plumes"); B. Sher Tinsley, Pierre Bayle's Reformation. Conscience and critism on the eve of the Enlightenment, Associated UP, London 2001, s. 317-318; J. Vercruysse, Crellius, Le Cène, Naigeon ou les chemins de la tolérance socinienne, „Tijdschrift voor de Studie van de Verlichting", 1973, 1, s. 244-320. 
Locke $^{202}$, a przypuszczalnie także Baruch Spinoza, John Milton ${ }^{203}$, Thomas Hobbes, Anthony Asham ${ }^{204}$ czy Isaac Newton ${ }^{205}$.

Dla uchwycenia ewolucji jego poglądów i ich znaczenia w momencie historycznym niezbędne jest jednak wyjście poza wybór pism egzegetycznych w Bibliotheca Fratrum Polonorum ku pismom polemicznym. Pozwala to dostrzec aktualne znaczenie refleksji teologicznej - bliskiej Faustowi Socynowi, Wolzogenowi czy Przypkowskiemu - a także jej ewolucję. Powyżej starano się pokazać, jak funkcje polemik wyznaniowych zmieniały się z biegiem lat, a także dowieść, że ewolucja poglądów Szlichtynga zmierzała ku podjęciu dialogu z innymi wyznaniami protestanckimi, zwłaszcza z reformowanymi. Otwarcie to polegało na uznaniu boskości Chrystusa, podkreśleniu roli jego ofiary w dziele usprawiedliwienia oraz pominięciu kwestii predestynacji. Ponadto, dzięki akceptacji instytucji świeckiego prawa, państwa oraz wojny obronnej socynianizm stawał się politycznie akceptowalny dla większości społeczeństwa. Propozycje rozwiązania kryzysu politycznego, do którego prowadziło współistnienie różnych wyznań roszczących sobie wyłączne prawo do interpretacji rzeczywistości i definiowania prawdy, należały do szerokiego nurtu irenicznego, rozkwitłego pod wpływem katastrofy wojny trzydziestoletniej.

Do tego nurtu należał również Jan Amos Komeński, twierdzący w Panegiryku, „że wolne powinno być wszystko: ciała, umysły, sumienia,

202 J. Marshall, Locke, Socinianism, and Unitarianism, w: English Philosophy in the Age of Locke, ed. M. A. Stewart, Clarendon Press, Oxford 2000, s. 111-182; Id., John Locke, Toleration and early Enlightenment culture, Cambridge UP, Cambridge 2006, s. 314, 319, 494. Por. N. Jolley, Leibniz on Locke and Socinianism, "Journal of the History of Ideas", 1978, 39, s. 233-250.

203 Por. J. Milton, Complete prose works, t. 6, ed. D. M. Wolfe, Yale UP, New Haven 1953-1982, s. 210, 213, 218, 237, 242, 244, 246-250, 256, 261-62, 275, 278, 289;

J. Rogers, Milton and the heretical priesthood of Christ, w: Heresy, literature, and politics in Early Modern England, ed. D. Loewenstein, J. Marshall, Cambridge UP, Cambridge 2006, s. 203-220.

204 Por. S. Mortimer, Reason and religion in the English Revolution: The challenge of Socinianism, Cambridge UP, Cambridge 2010, s. 115-116.

205 Por. S. D. Snobelen, "God of Gods, and Lord of Lords”: The theology of Isaac Newton's General Scholium to the Principia, „Osiris”, 2001, 16, s. 169-208; Id., Socinianism and Newtonianism: the case of William Whiston, w: Faustus Socinus, s. 373-414; E. Scribano, Samuel Colliber: A Socinian in Newton's age, w: ibidem, s. 415-422. Por. J. McLachlan, Socinianism in seventeenth-century England, Oxford UP, Oxford 1951; J. Tazbir, Stanistaw Lubieniecki, przywódca ariańskiej emigracji, PWN, Warszawa 1961, s. 266; J. Jørgensen, Stanistaw Lubieniecki, s. 186-187. 
tak by nikt nie narzucał drugiemu kajdan pod tym lub owym, lub innym względem"206. Ten postulat wykraczał poza oczekiwania realizacji Konfederacji Warszawskiej i posiadanych praw, co nazwano powyżej stanową koncepcją wolności. Żądanie wolności „ciał, umysłów i sumień” było niemal dosłownie zaczerpnięte z Apologii opublikowanej przez Szlichtynga w 1654 r. i odpowiadało postulowanej przez arianina nowej koncepcji indywidualnej wolności, przysługującej każdemu człowiekowi, niezależnie od jego pozycji społecznej czy wiary. Te podobieństwa świadczą być może o tym, że wysuwane pod adresem Komeńskiego zarzuty o sympatie socyniańskie nie były bezpodstawne. $\mathrm{Z}$ pewnością natomiast obaj teologowie należeli do pionierów nowych idei i sposobów myślenia.

Szlichtyng zasługuje na miano prekursora oświecenia, choć sąd ten wymaga doprecyzowania. Z jednej strony przemawiają za tym kluczowe elementy jego światopoglądu: obrona niezależności i wolności jednostki, pochwała tolerancji, rozdział państwa i kościoła czy dość specyficzny „,racjonalizm religijny”. Istotnie, wszystkie te idee znajdowały życzliwy odbiór w wieku XVIII, w środowiskach myślicieli epoki świateł, zwłaszcza wśród przedstawicieli „radykalnego oświecenia”, którym zarzucano „naturalizm”, „materializm”, a nawet „ateizm”207. Trzeba więc zastrzec, że oświeceniowy światopogląd Szlichtynga był ugruntowany w jego poglądach teologicznych. Wolność i racjonalność jednostki wiązaty się ściśle z negacją brzemienia grzechu pierworodnego, a także z nauką o usprawiedliwieniu i predestynacji. Te ostatnie wynikały z przekonań na temat Chrystusa, Ducha Świętego i całej Trójcy.

Z drugiej strony należy pamiętać, że podkreślanie roli pobożności i przemiany życiowej („fides viva”, „charitas”, „praxis pietatis”) zbliżało Szlichtynga do nurtu myślicieli i praktyków „drugiej reformacji”, którzy domagali się „reformatio vitae”, następującej za pierwszą reformacją ${ }^{208}$. Do owych ruchów odnowy religijnej drugiej połowy XVII i początku XVIII w., będących reakcją na skostnienie ortodoksyjnych nurtów reformacji, należy przede wszystkim pietyzm, ale podobne zjawiska można zaobserwować także w Kościele katolickim (jansenizm) oraz w religii żydowskiej (chasydyzm) ${ }^{209}$. Uważna lektura myślicieli socyniańskich

206 Cyt. za Filozofia i myśl, s. 288.

207 Por. J. Israel, The radical Enlightenment: Philosophy and the making of modernity 1650-1750, Oxford UP, Oxford 2001, s. 205-208.

208 Por. W. Kriegseisen, Stosunki wyznaniowe, s. 37.

209 Por. J. Strom, Problems and Promises of Pietism Research, „Church History”, 2002, 71, s. 536-554. 
powinna skłonić do rozszerzenia tego katalogu o ich nazwiska. Sprzeczność obu powyższych interpretacji, zaliczających Szlichtynga bądź do prekursorów oświecenia, bądź do grona „ponadwyznaniowego pietyzmu” jest pozorna - obie powyżej sformułowane tezy wpisują się w szerszą refleksję na temat religijnych korzeni europejskiego oświecenia ${ }^{210}$.

Stwierdzenie, że wygnanie braci polskich z Rzeczypospolitej oznaczało symboliczny koniec epoki tolerancji, w świetle najnowszych ustaleń zasługuje na rewizję. Modyfikację tej generalnej tezy zaproponował Kriegseisen, twierdząc, że w XVI-XVII w. „tolerancja wyznaniowa w praktyce życia społecznego nowożytnej Europy to po prostu wolność od prześladowań na tle wyznaniowym czy religijnym" ${ }^{211}$ oraz że przemiany XVII w. wpisywały się w ogólnoeuropejski proces konfesjonalizacji, który w warunkach Rzeczypospolitej był z opóźnieniem inicjowany przez Kościół katolicki. Ta nowa interpretacja pozwala umieścić los braci polskich w ramach ogólnoeuropejskiego procesu konfesjonalizacji. Podstawą swobody wyznaniowej XVI stulecia w Rzeczypospolitej było opóźnienie procesów budowania konfesji. Natomiast starcie ortodoksji i heterodoksji miało w nowożytnej Europie powszechny charakter i wynikało z procesów formowania tożsamości konfesyjnej grup wyznaniowych oraz wypracowywania modelu współistnienia w ramach jednej organizacji państwowej. Procesy te miały różną dynamikę i odmienny przebieg dla poszczególnych wyznań. W starciach konfesyjnych heterodoksja określała i modyfikowała własne stanowisko, wypracowując zarazem własną ortodoksję i walcząc o jej polityczne uznanie ${ }^{212}$. Innymi słowy, starcie między braćmi polskimi a pozostałymi wyznaniami było typową konfrontacją epoki konfesjonalizacji, a zbór mniejszy przechodził tę samą ewolucję, co inne kościoły ${ }^{213}$.

210 Por. D. Sorkin, The Religious Enlightenment. Protestants, Jews and Catholics from London to Vienna, Princeton UP, Princeton 2008, s. 6-11; H. Trevor-Roper, The Crisis of the Seventeenth Century: Religion, the Reformation and Social Change, Macmillan, London 1967, s. 179-218. Por. uwagi w: U. L. Lehner, The Many Faces of the Catholic Enlightenment, w: A Companion to the Catholic Enlightenment in Europe, ed. U. L. Lehner, M. Printy, Brill, Leiden 2010, s. 1-61.

211 W. Kriegseisen, Stosunki wyznaniowe, s. 27.

212 Por. L. Kołakowski, Świadomość religijna i więź kościelna, PWN, Warszawa 1997, s. 51-53.

213 Por. J. Dworzaczkowa, Bracia czescy $w$ Wielkopolsce $w$ XVI i XVII wieku, Wydawnictwo Naukowe Semper, Warszawa 1997, s. 14-15. 


\section{Polish Toleration or the Beginning of the Enlightenment? Jonasz Szlichtyng (1592-1661) as Theologian of the second Reformation}

The article deals with socianian theologian, Jonasz Szlichtyng (Jonas Schlichting), who was the main pastor in Raków, the centre of socinians (called the Polish Brethren), in the times when they suffered the hardest persecutions which led to their expulsion from Poland in 1658. His exegetical works, reprinted in the Bibliotheca Fratrum Polonorum, were very popular among the intellectuals on the eve of the Enlightenment.

The historiography interpreted the change of the attitude towards the Polish Brethren in terms of the transition from the religious toleration of the $16^{\text {th }}$ century towards the persecutions and intolerance of the $17^{\text {th }}$ century. The Brethren were perceived either as successor of the ideas of toleration and a cradle of the Enlightenment, or a traitor of the "Polish nation". In the essay, these general theses are repudiated upon the analysis of the Szlichtyng's thought.

The author focused on Trinitology, Christology, Soteriology, and Szlichtyng's attitude towards the secular and ecclesiastical authorities. The reconstruction is based on Szlichtyng's polemics and some of his exegetical writings. According to the author, Szlichtyng was a typical theologian of the "second reformation" who stressed the role of the piety and a need for change of believers' lifestyle.

By demonstrating the evolution of Szlichtyng's opinions in the eve of Colloquium Charitativum (Toruń, 1645), the author claims that Szlichtyng made an effort to bring the Brethren closer to other protestant confessions. The author argues that Szlichtyng attempted to reconcile the socinians with the Calvinists. The efforts of Szlichtyng as well as the banishment of Brethren belonged to the process of the confessional development of $17^{\text {th }}$ century, comparable with evolution of other religious communities in Europe. 